\title{
Krajowy Mechanizm Prewencji Tortur w oczach funkcjonariuszy Służby Więziennej
}

\author{
ZBIGNIEW LASOCIK \\ ORCID: 0000-0002-1921-1073 \\ Ośrodek Badań Handlu Ludźmi \\ Uniwersytetu Warszawskiego \\ AnNa MęzIK \\ ORCID: 0000-0003-3358-6506
}

Wydział Nauk Politycznych i Studiów Międzynarodowych

\section{Wstęp}

Celem opracowania jest przedstawienie wyników badań przeprowadzonych wśród funkcjonariuszy i pracowników Służby Więziennej, dotyczących wiedzy i opinii przedstawicieli tej grupy zawodowej na temat Krajowego Mechanizmu Prewencji Tortur (dalej: KMPT, Mechanizm).

Tytułem wstępu należy wyjaśnić, że Krajowy Mechanizm Prewencji Tortur to instytucja powołana na mocy Protokołu fakultatywnego do Konwencji ONZ w sprawie zakazu stosowania tortur oraz innego okrutnego, nieludzkiego lub poniżającego traktowania albo karania (dalej: OPCAT, Protokół fakultatywny, Protokół) ${ }^{1}$. Więcej szczegółów na temat Protoko-

${ }^{1}$ Protokół fakultatywny do Konwencji w sprawie zakazu stosowania tortur oraz innego okrutnego, nieludzkiego lub poniżającego traktowania albo karania, przyjęty przez 
łu, a także samej instytucji, w tym jej mandatu i historii, w dalszej części tekstu, tu powiedzmy tylko, że w Polsce funkcję KMPT pełni Rzecznik Praw Obywatelskich (dalej: RPO lub Rzecznik). Natomiast podstawowym zadaniem Mechanizmu jest podejmowanie działań, które mają prowadzić do skutecznego zapobiegania torturom i wszelkim formom okrutnego, nieludzkiego czy poniżającego traktowania albo karania.

\section{Geneza Krajowego Mechanizmu Prewencji Tortur}

Zakaz tortur jako jedno z najważniejszych osiągnięć cywilizacji powojennej został jednoznacznie sformułowany w art. 5 Powszechnej deklaracji praw człowieka ${ }^{2}$ uchwalonej przez Zgromadzenie Ogólne Organizacji Narodów Zjednoczonych 10 grudnia 1948 roku. Artykuł ten stanowi, że nikt nie będzie poddany torturom lub okrutnemu, nieludzkiemu, poniżającemu traktowaniu lub karaniu. Pomimo że Powszechna deklaracja praw człowieka formalnie nie ma charakteru wiążącego, jej postanowienia uznane są za takie ze względu na jej wyjątkowe znaczenie aksjologiczne dla systemu ochrony praw człowieka, który powstał po drugiej wojnie światowej ${ }^{3}$.

Ponownie, choć tym razem już w wiążącym prawnie traktacie, zakaz tortur został powtórzony w art. 7 Międzynarodowego paktu praw obywatelskich i politycznych z 1966 roku (dalej: Pakt) ${ }^{4}$, który został ratyfikowany przez Polskę w 1977 roku $^{5}$. Tym razem zakres regulacji został poszerzony o zakaz poddawania kogokolwiek, bez jego swobodnie wyrażonej zgody, doświadczeniom lekarskim lub naukowym. Ponadto w art. 10 ust. 1 Paktu prawodawca międzynarodowy sformułował zasadę

Zgromadzenie Ogólne Narodów Zjednoczonych w Nowym Jorku dnia 18 grudnia 2002 roku, Dz.U. z 2007 r. Nr 30, poz. 192. Skrót OPCAT, którym posługujemy się w dalszej części artykułu, pochodzi od angielskiej nazwy tego dokumentu: Optional Protocol to the Convention against Torture.

2 Powszechna deklaracja praw człowieka, rezolucja Zgromadzenia Ogólnego ONZ 217 A (III) przyjęta i proklamowana w dniu 10 grudnia 1948 roku w Paryżu.

${ }^{3}$ M. Balcerzak, Podstawy międzynarodowej ochrony praw człowieka. Zarys wykładu z materiałami źródłowymi, Toruń 2017, s. 39.

4 Międzynarodowy pakt praw obywatelskich i politycznych rezolucja Zgromadzenia Ogólnego ONZ nr 2200A (XXI) z 16 grudnia 1966 roku.

${ }^{5}$ Międzynarodowy pakt praw obywatelskich i politycznych otwarty do podpisu w Nowym Jorku dnia 19 grudnia 1966 roku, Dz.U. Z 1977 r. Nr 38, poz. 167.

Nowa Kodyfikacja Prawa Karnego 54, 2019

(C) for this edition by CNS 
humanitarnego traktowania osób pozbawionych wolności, z poszanowaniem przyrodzonej im godności.

W latach siedemdziesiątych XX wieku masowe stosowanie tortur przez dyktatury na całym świecie doprowadziło do kilku inicjatyw mających na celu opracowanie nowych instrumentów prawnych, których celem byłoby wyeliminowanie takich praktyk oraz skuteczne karanie sprawców. Jedną z nich była akcja Amnesty International ${ }^{6}$ z 1973 roku w obronie brazylijskiego więźnia politycznego, któremu groziły tortury ze strony junty wojskowej, która wywarła znaczący wpływ na międzynarodową opinię publiczną i doprowadziła do rozpoczęcia prac nad podwyższeniem standardu w zakresie zakazu stosowania tortur ${ }^{7}$. Równolegle w latach siedemdziesiątych XX wieku za sprawą szwajcarskiego bankiera, prawnika i działacza społecznego Jeana Jacques’a Gautiera narodziła się idea zapobiegania torturom i innym formom okrutnego, nieludzkiego lub poniżającego traktowania albo karania poprzez wizytowanie miejsc pozbawienia wolności przez niezależnych ekspertów. W jakimś sensie wzorem były wizytacje miejsc odosobnienia prowadzone przez Międzynarodowy Komitet Czerwonego Krzyża w trakcie wojen. J.J. Gautier rozpoczął budowę koalicji mającej na celu promowanie systemu regularnych wizyt niezależnych ekspertów, które dotyczyłyby wszystkich miejsc izolacji. Jego koncepcja spotkała się z zainteresowaniem kilku międzynarodowych organizacji pozarządowych, między innymi Amnesty International oraz Międzynarodowej Komisji Prawników (ICJ) ${ }^{8}$.

Mniej więcej w tym samym czasie trwały prace nad konwencją, która uregulowałaby sprawę zakazu tortur nieco bardziej precyzyjnie niż Międzynarodowy pakt praw obywatelskich i politycznych. Był to znako-

${ }^{6}$ Zob. https://amnesty.org.pl/pilne-akcje-takiej-przesy\%C5\%82ki-\%C5\%BCadenrz\%C4\%85d-zlekcewa\%C5\%BCy\%C4\%87-nie-mo\%C5\%BCe (dostęp: 27.12.2018). Amnesty International jest istniejącą od 1961 roku międzynarodową organizacją pozarządową działającą na rzecz ochrony praw człowieka: https://amnesty.org.pl/o-nas/ (dostęp: 27.12.2018).

${ }^{7}$ N. Boeglin, History of the Optional Protocol to the UN Convention against torture, [w:] N. Boeglin-Naumovic, D. Long, Optional protocol to the United Nations Convention against Torture and other Cruel, Inhuman or Degrading Treatment or Punishment. A manual for prevention, Genewa-San José 2005, s. 38.

8 N. Boeglin, op. cit., s. 38-39; oraz J.H. Burgers, H. Danelius, The United Nations Convention against torture. A handbook on the convention against torture and other cruel, inhuman, or degrading treatment or punishment, Dordrecht-Boston-London 1988, s. 26 n. Nowa Kodyfikacja Prawa Karnego 54, 2019

(C) for this edition by CNS 
mity pretekst dla przeciwników kontrowersyjnego pomysłu Gautiera, aby prace nad zaproponowanym rozwiązaniem odłożyć do czasu przyjęcia nieco bardziej ogólnych rozwiązań ${ }^{9}$. Wielu państwom trudno było zaakceptować sytuację, w której niezależny organ międzynarodowy może na miejscu badać sytuację w miejscach pozbawienia wolności. Władze tych państw postrzegały to jako nadmierną ingerencję w ich suwerenność. To dlatego, antycypując opór wielu krajów przed poparciem systemu wizytacji więziennych, sekretarz generalny MKP (Międzynarodowej Komisji Prawników) Niall McDermot zaproponował, aby pomysł J.J. Gautiera znalazł odzwierciedlenie w przepisach protokołu dodatkowego do przygotowywanego ówcześnie traktatu. Tak też się stało ${ }^{10}$.

Ostatecznie traktat ten przyjął postać Konwencji w sprawie zakazu stosowania tortur oraz innego okrutnego, nieludzkiego lub poniżającego traktowania albo karania ${ }^{11}$ (dalej: Konwencja ONZ w sprawie zakazu stosowania tortur, Konwencja ONZ), która została przyjęta przez Zgromadzenie Ogólne Organizacji Narodów Zjednoczonych 10 grudnia 1984 roku, a weszła w życie w 1987 roku. Polska ratyfikowała tę Konwencję 26 lipca 1989 roku $^{12}$. Jest to najbardziej kompleksowy akt prawa międzynarodowego dotyczący zakazu tortur. W art. 1 Konwencji zostało zdefiniowane pojęcie tortur. W definicji tej istotne są trzy elementy: sprawca — musi to być funkcjonariusz publiczny lub inna osoba urzędowa; cel, którym jest działanie nakierowane na uzyskanie informacji, zastraszenie lub ukaranie ofiary oraz skutek tego działania w postaci ostrego cierpienia fizycznego lub psychicznego ${ }^{13}$. Konwencja w art. 2 ust. 2 stanowi,

${ }^{9}$ M.D. Evans, C. Haenni-Dale, Preventing torture? The development of the Optional Protocol to the UN Convention against Torture, „Human Rights Law Review” 4, 2004, z. 1. s. 23-24; oraz R. Murray et al., The Optional Protocol to the UN Convention Against Torture, Oxford 2011, s. 9-10.

10 Ibidem, s. 8-10.

11 Konwencja w sprawie zakazu stosowania tortur oraz innego okrutnego, nieludzkiego lub poniżającego traktowania albo karania przyjęta przez Zgromadzenie Ogólne ONZ 10 grudnia 1984 roku A/RES/39/46.

12 Konwencja w sprawie zakazu stosowania tortur oraz innego okrutnego, nieludzkiego lub poniżającego traktowania albo karania, przyjęta przez Zgromadzenie Ogólne Narodów Zjednoczonych dnia 10 grudnia 1984 roku, Dz.U. 1989 r. Nr 63, poz. 378.

13 Z. Lasocik, Zakaz tortur - systemowe gwarancje wolności od tortur w instytucjach izolujacych, [w:] Modernizowanie więziennictwa V Kongres Penitencjarny, red. T. Bulenda, A. Rzepliński, Warszawa 2015, s. 556.

Nowa Kodyfikacja Prawa Karnego 54, 2019

(C) for this edition by CNS 
że wolność od tortur jest wolnością absolutną niepodlegającą żadnym ograniczeniom w żadnych okolicznościach.

Na mocy przepisów Konwencji został powołany do życia Komitet Przeciwko Torturom (dalej: CAT ${ }^{14}$ ), którego zadaniem jest badanie realizacji postanowień Konwencji przez państwa strony. Komitet realizuje to zadanie poprzez analizę i weryfikację raportów składanych co cztery lata przez państwa strony, w tym także przez Polskę ${ }^{15}$. Na mocy art. 20 Konwencji CAT ma prawo zbadania sprawy, również na terytorium państwa strony, w wypadku otrzymania wiarygodnej informacji o systematycznym stosowaniu tortur na jego terytorium. Przepis ten budził wiele kontrowersji, jednak ostatecznie został włączony do tekstu Konwencji, przy czym państwa strony mają możliwość złożenia oświadczenia o niepodleganiu tej procedurze ${ }^{16}$.

Ponieważ idea stworzenia systemu wizytacji więziennych pod auspicjami ONZ została odroczona, rozpoczęły się działania zmierzające do wprowadzenia systemu niezależnych wizytacji na poziomie regionalnym. Niewątpliwym liderem w tych pracach okazała się Europa. W 1983 roku Zgromadzenie Parlamentarne Rady Europy przyjęło opracowany przez Szwajcarski Komitet przeciwko Torturom i Międzynarodową Komisję Prawników projekt systemu wizytacji ${ }^{17}$. Natomiast cztery lata później, 26 czerwca 1987 roku, Rada Europy przyjęła Europejską konwencję o zapobieganiu torturom oraz nieludzkiemu lub poniżającemu trraktowaniu albo karaniu (dalej: ECPT) ${ }^{18}$. Konwencja ta ustanowiła Europejski Komi-

14 Akronim pochodzi angielskiej nazwy Komitetu: Committee Against Torture.

15 W dniach 22-24 lipca 2019 roku Komitet rozpatrywał siódme okresowe sprawozdanie Polski z realizacji Konwencji w sprawie zakazu stosowania tortur oraz innego okrutnego, nieludzkiego lub poniżającego traktowania albo karania. Komitet sformułował także wnioski i rekomendacje (concluding observations) wynikające z analizy tego sprawozdania oraz serii przesłuchań przedstawicielu rządu oraz ekspertów. Nie wchodząc w szczegóły, można powiedzieć tylko, że ogólna ocena postępów Polski w eliminowaniu tortur nie była szczególnie wysoka. Komitet powtórzył wiele zastrzeżeń, które formułował poprzednio, więcej na ten temat zob. https://tbinternet.ohchr.org/_layouts/15/ paternalistyczny/Download.aspx?symbolno=CAT\%2fC $\% 2 \mathrm{fPOL} \% 2 \mathrm{fCO} \% 2 \mathrm{f} 7 \& \mathrm{Lang}=\mathrm{en}$ (dostęp: 8.09.2019).

16 M.D. Evans, C. Haenni-Dale, op. cit., s. 21.

17 N. Boeglin, op. cit., s. 40.

18 Europejska konwencja o zapobieganiu torturom oraz nieludzkiemu lub poniżającemu traktowaniu albo karaniu, sporządzona w Strasburgu w dniu 26 listopada 1987 roku, Dz.U. z 1995 r. Nr 46, poz. 238.

Nowa Kodyfikacja Prawa Karnego 54, 2019

(C) for this edition by CNS 
tet do spraw Zapobiegania Torturom oraz Nieludzkiemu lub Poniżającemu Traktowaniu albo Karaniu (dalej: CPT), którego głównym zadaniem jest wizytowanie miejsc pozbawienia wolności $\mathrm{w}$ dowolnym państwie członkowskim Rady Europy, które ratyfikowało Konwencję.

Prace nad stworzeniem podobnego systemu wizytacji prewencyjnych były również prowadzone w Ameryce Południowej i Ameryce Północnej, jednak przyjęta w 1985 roku Międzyamerykańska konwencja w sprawie zapobiegania torturom i karania za ich stosowanie ${ }^{19}$ nie stworzyła podobnego mechanizmu prewencyjnego ${ }^{20}$.

Po wejściu w życie Konwencji ONZ w roku 1987 rozpoczęły się działania Szwajcarskiego Komitetu przeciwko Torturom i Międzynarodowej Komisji Prawników, których celem był powrót do idei utworzenia uniwersalnego systemu prewencyjnych wizytacji miejsc pozbawienia wolności ${ }^{21}$. Poparcie dla samego pomysłu oraz inicjatyw tych dwóch organizacji nich wyraził między innymi Specjalny Sprawozdawca ONZ do spraw Tortur ${ }^{22}$. W 1991 roku Kostaryka złożyła projekt protokołu dodatkowego do Konwencji ONZ ${ }^{23}$, natomiast w następnym roku Komisja Praw Człowieka ONZ powołała Grupę Roboczą, której zadaniem było opracowanie ostatecznego projektu takiego protokołu. W pracach tego gremium uczestniczyli przedstawiciele państw członkowskich ONZ oraz organizacji pozarządowych, a także niezależni eksperci. Przez osiem lat trwały trudne dyskusje nad stworzeniem międzynarodowej instytucji wizytującej. Główne punkty sporne dotyczyły: potrzeby tworzenia nowego instrumentu zapobiegania torturom, który zdaniem części uczestników powielałby działania innych organizacji międzynarodowych takich jak CPT czy CAT; sposobu finansowania działalności nowego mechanizmu — czy ma być finansowany z budżetu ONZ, czy przez państwa strony. Jednakże najwięcej kontrowersji wzbudzał zakres uprawnień ciała

19 Międzyamerykańska konwencja w sprawie zapobiegania torturom i karania za ich stosowanie z 9 grudnia 1985 roku, tekst Konwencji w języku angielskim jest dostępny na stronie http://www.oas.org/juridico/english/treaties/a-51.html (dostęp: 27.12.2018).

20 Optional protocol to the UN Convention against torture. Implementation manual, revised edition, Association for the Prevention of Torture (APT) Inter-American Institute for Human Rights (IIHR),Genewa-San José 2010, s.17.

21 N. Boeglin, op. cit., s. 42.

22 J.H. Burgers, H. Danelius, op. cit., s. 28-29.

23 N. Boeglin, op. cit., s. 42.

Nowa Kodyfikacja Prawa Karnego 54, 2019

(C) for this edition by CNS 
wizytującego ze względu na obawy państw związane z ograniczeniem ich suwerenności i możliwą ingerencją w kwestie bezpieczeństwa narodowego. Część państw, uczestników negocjacji postulowała stworzenie ograniczonej listy miejsc, które mogą być wizytowane. W trakcie dyskusji pojawiła się też propozycja, aby wizyty były zapowiadane, a także żeby państwo strona mogło nie wyrazić zgody na wizytowanie więzień na swoim terytorium ${ }^{24}$. Kontrowersje dotyczyły także tego, jaki charakter powinny mieć rekomendacje powizytacyjne ${ }^{25}$.

W 2001 roku Meksyk złożył propozycję, aby w uzupełnieniu do działań mechanizmu uniwersalnego ustanowić mechanizmy/instytucje wizytujące na poziomie krajowym ${ }^{26}$. Choć spotkała się ona $\mathrm{z}$ mieszanymi reakcjami uczestników prowadzonych negocjacji, to jednak już w 2002 roku przewodnicząca Grupy Roboczej Elizabeth Odio Benito przedstawiła kompromisowy tekst Protokoła ${ }^{27}$. Protokół fakultatywny do Konwencji ONZ w sprawie zakazu stosowania tortur oraz innego okrutnego, nieludzkiego lub poniżającego traktowania albo karania został ostatecznie przyjęty przez Zgromadzenie Ogólne ONZ 18 grudnia 2002 roku $^{28}$.

Wyjątkowość Protokołu fakultatywnego na tle innych konwencji dotyczących praw człowieka polega na tym, że koncentruje się na prewencji, a nie na następczej reakcji na naruszenia. W przepisach Protokołu kładzie się nacisk na potrzebę dialogu między instytucjami wizytującymi a władzami państwa, a nie na kontrolę ${ }^{29}$. Protokół stanowi uzupełnienie do Konwencji w sprawie zakazu stosowania tortur, jest praktycznym narzędziem mającym ułatwić podejmowanie działań prowadzących do eliminacji stosowania tortur ${ }^{30}$. Głównie dzięki temu, że powstał system

24 Ibidem, s. 45-46.

25 M.D. Evans, C. Haenni-Dale, op. cit., s. 35-36.

26 Ibidem, s. 27.

27 Optional Protocol..., s.6 oraz s. 17-18.

28 Protokół fakultatywny do Konwencji w sprawie zakazu stosowania tortur oraz innego okrutnego, nieludzkiego lub poniżającego traktowania albo karania przyjęty przez Zgromadzenie Ogólne ONZ 18 grudnia 2002 roku, A/RES/57/199 Dz.U. z 2007 r. Nr 30, poz. 192.

29 E. Dawidziuk, Traktowanie osób pozbawionych wolności we współczesnej Polsce na tle standardów międzynarodowych, Warszawa 2013, s. 33.

30 Optional Protocol..., s. 11.

Nowa Kodyfikacja Prawa Karnego 54, 2019

(C) for this edition by CNS 
uzupełniających się mechanizmów zapobiegania torturom na poziomie uniwersalnym i na poziomie krajowym.

Na mocy postanowień OPCAT powołano do życia Podkomitet do spraw Prewencji Tortur ONZ (dalej: SPT ${ }^{31}$, Podkomitet), który został zaliczony do kategorii tak zwanych ciał traktatowych ONZ (UN treaty bodies $)^{32}$. Natomiast gdy chodzi o państwa przystępujące do Protokołu, jego przepisy nakładają obowiązek utworzenia minimum jednego lokalnego krajowego mechanizmu prewencji tortur (ang. National Preventive Mechanisms). W ten sposób Protokół buduje trójstronną relację między Podkomitetem do spraw Prewencji, krajowym mechanizmem prewencji tortur a państwem ${ }^{33}$.

Lektura art. 1 OPCAT nie pozostawia wątpliwości, że Protokół powstał po to, aby ustanowić system regularnych wizyt prewencyjnych w celu zapobiegania torturom oraz innemu nieludzkiemu lub poniżającemu traktowaniu albo karaniu, przeprowadzanych przez niezależne międzynarodowe i krajowe organy w miejscach, w których przebywają osoby pozbawione wolności. Natomiast art. 4 ust. 2 stanowi, że na potrzeby Protokołu pozbawienie wolności rozumiane jest jako jakakolwiek forma zatrzymania lub uwięzienia bądź umieszczenia człowieka w publicznym lub prywatnym miejscu odosobnienia, którego tej osobie nie wolno z własnej woli opuszczać, na mocy polecenia jakiejkolwiek władzy sądowej, administracyjnej lub innej. Cytujemy te dwa przepisy, ponieważ pozwalają zrozumieć istotę i doniosłość OPCAT. Ten pierwszy dlatego, że określa proces nieznany wcześniej żadnej innej instytucji międzynarodowej — regularne prewencyjne wizyty ekspertów w miejscach pozbawienia wolności. Wszystkie użyte tu słowa są ważne, jednak kluczowe jest słowo ,prewencja”. Wizyta ma charakter prewencyjny wtedy, kiedy odbywa się po to, aby minimalizować ryzyko negatywnych zachowań personelu — zatem ma miejsce regularnie, bez uprzedzenia i jest prowadzona przez osobę, która potrafi ocenić groźbę takich zachowań. Ten drugi przepis jest ważny, ponieważ zawiera najszerszą legalną definicję

31 SPT skrót od nazwy w języku angielskim: Subcommittee on Prevention of Torture and other Cruel, Inhuman or Degrading Treatment or Punishment.

32 Więcej na ten temat zob. https://www.ohchr.org/EN/HRBodies/Pages/TreatyBodies.aspx (dostęp: 27.10.2019).

33 Optional Protocol..., s. 13-15.

Nowa Kodyfikacja Prawa Karnego 54, 2019

(C) for this edition by CNS 
pozbawienia wolności. Gdy wczytać się w tę definicję, oczywisty staje się wniosek, że w normalnie funkcjonującym państwie nie ma takiego miejsca odosobnienia (karnego, administracyjnego, medycznego itp.), które nie podlegałoby wizytacji w ramach OPCAT.

Podkomitet do spraw Prewencji Tortur w odróżnieniu od innych ciał traktatowych, jak CAT czy Komitet Praw Człowieka, nie ma kompetencji do przyjmowania i oceny regularnych sprawozdań państw z wypełniania zobowiązań zawartych Konwencji ONZ ${ }^{34}$. Natomiast ma prawo wizytowania miejsc pozbawienia wolności, o których właśnie była mowa. Po przeprowadzeniu wizytacji SPT niezwłocznie przedstawia państwu stronie swoją wstępną ocenę sytuacji oraz najszybciej jak to możliwe ocenę pogłębioną oraz rekomendacje, o ile są uzasadnione (art. 11a OPCAT). Formułując je, bierze pod uwagę warunki pozbawienia wolności, ale także, a może przede wszystkim, bada, czy i w jakim zakresie realizowane są podstawowe gwarancje bezpieczeństwa osób pozbawionych wolności, takie jak prawo do badania stanu zdrowia czy prawo do kontaktu z adwokatem. W czasie wizyty członkowie SPT są zobowiązani do przestrzegania prawa wizytowanego państwa strony oraz do zachowania bezstronności (art. 36 OPCAT). Przebieg wizyty, wstępna ocena Podkomitetu, pogłębiona ocena, rekomendacje oraz wszelkie kontakty z władzami państwa strony objęte są zasadą poufności, gdyż celem nie jest potępianie wizytowanych, a poprawa sytuacji pozbawionych wolności wypracowana na drodze dialogu ${ }^{35}$. Na podstawie art. 16 ust. 2 Protokołu SPT publikuje raport z wizytacji na wniosek państwa strony.

Aby system mógł działać prawidłowo, odpowiednikiem uprawnień Podkomitetu są obowiązki państw stron. Na mocy art. 2 ust 4 oraz art. 14 ust. 1 OPCAT państwo, które przyjmuje delegację SPT, zobowiązane jest do jak najdalej idącej współpracy z jej członkami. Przede wszystkim, jak nakazuje art. 14. ust 1, zezwala ono na przeprowadzanie wizyt we wskazanych miejscach pozbawienia wolności oraz na indywidualne rozmowy z osobami pozbawionymi wolności, a także udostępnia wszelkie niezbędna informacje i dane. Na mocy art. 12 władze państwa przyjmującego są zobowiązane analizować oceny i rekomendacje formułowane przez SPT, prowadzić z nim dialog na temat realizacji zaleceń, a także

34 M. Balcerzak, op. cit., s. 123-127.

35 Zob. Optional Protocol..., s. 81; oraz M.D. Evans, C. Haenni-Dale, op. cit., s. 31-32. Nowa Kodyfikacja Prawa Karnego 54, 2019

(C) for this edition by CNS 
ułatwiać kontakty SPT z dowolnymi podmiotami krajowymi, które mogą w tym pomóc, włączając w to KMPT.

Podkomitet do spraw Prewencji początkowo składał się z dziesięciu członków, natomiast po ratyfikowaniu Protokołu przez pięćdziesiąte państwo stronę liczy dwudziestu pięciu członków (art. 5 ust. 1 OPCAT). Członkowie SPT są wybierani spośród kandydatów zgłoszonych przez państwa strony. Podkomitet rozpoczął swoją działalność w lutym 2007 roku. W latach 2007-2012 członkiem SPT był prof. Zbigniew Lasocik. Pierwsza wizyta Podkomitetu do spraw Prewencji Tortur ONZ w naszym państwie odbyła się w lipcu 2018 roku $^{36}$. Siedziba SPT znajduje się w Genewie.

Na mocy art. 3 i art. 17 OPCAT najpóźniej w ciągu roku od wejścia w życie ratyfikacji lub przystąpienia do Protokołu państwo strona jest zobowiązane do utworzenia, wyznaczenia lub utrzymania już istniejącego, jednego lub kilku niezależnych krajowych mechanizmów prewencji tortur (KMPT). Celem działania takiej instytucji jest szeroko rozumiane zapobieganie torturom na poziomie krajowym. Protokół nie przesądza formy organizacyjnej, w jakiej mają funkcjonować krajowe mechanizmy prewencji tortur, natomiast sporo uwagi poświęca gwarancjom ich skutecznego działania. Zostały one zawarte w art. 18 OPCAT, a sprowadzają się tego, że państwo strona ma obowiązek: zagwarantowania niezależności działania KMPT, podjęcia niezbędnych kroków w celu zapewnienia, by członkowie mechanizmu mieli odpowiednie umiejętności i wiedzę czy wreszcie przyznania adekwatnych środków finansowych na działanie mechanizmu.

Aby zapewnić efektywne działanie KMPT, proces jego tworzenia powinien być jawny i przejrzysty. W dyskusję na temat kształtu KMPT powinny być zaangażowane państwowe organy zajmujące się prawami człowieka, krajowe organizacje pozarządowe, przedstawiciele partii politycznych i urzędnicy administracji publicznej, mający odpowiednią wiedzę zawodową, oraz organy wizytujące miejsca pozbawienia wolności ${ }^{37}$.

Podobnie jak w wypadku Podkomitetu do spraw Prewencji Tortur państwo strona jest zobowiązane do umożliwienia mechanizmowi krajo-

36 https://tbinternet.ohchr.org/_layouts/TreatyBodyExternal/CountryVisits.aspx?SortOrder=Chronological\# (dostęp: 29.12.2018).

37 Przewodnik tworzenie Krajowych Mechanizmów Prewencji, przeł. Stowarzyszenie Interwencji Prawnej, Warszawa 2008, s. 13, https:/watch.interwencjaprawna.pl/pliki/ tworzenie-kmp.pdf (dostęp: 14.06.2018).

Nowa Kodyfikacja Prawa Karnego 54, 2019

(C) for this edition by CNS 
wemu pełnego dostępu do miejsc pozbawienia wolności oraz wszelkich niezbędnych informacji (art. 20 a-e OPCAT). Natomiast na mocy art. 22 Protokołu państwo strona jest zobowiązane do analizowania rekomendacji mechanizmów zawartych w raporcie sporządzonym po wizytacji oraz nawiązywania dialogu na temat możliwych środków ich realizacji. Jakiekolwiek poufne informacje zebrane przez ekspertów krajowego mechanizmu nie mogą być opublikowane bez zgody osób, których dotyczą (art. 21 ust. 2 OPCAT). Jednocześnie na mocy art. 15 i art. 21 ust. 1 OPCAT państwo strona nie może stosować żadnych sankcji wobec osób, które udzieliły informacji wysłannikom SPT oraz członkom mechanizmu krajowego. I wreszcie - art. 23 OPCAT zobowiązuje państwo stronę do publikowania i rozpowszechniania raportów z wizytacji rocznych mechanizmu.

Jak już była mowa, OPCAT nie przesądza, jaką formę organizacyjną ma przybrać mechanizm krajowy, natomiast w literaturze przedmiotu wymienia się cztery rozwiązania modelowe $\mathrm{e}^{38}$. W pierwszym powoływana jest zupełnie nowa instytucja, w drugim funkcję krajowego mechanizmu prewencji tortur pełni krajowa instytucja praw człowieka, jak ombudsman czy komisja praw człowieka, w trzecim modelu to krajowa instytucja praw człowieka wypełnia zadania KMPT wspólnie z organizacjami pozarządowymi i czwarty model, w którym zadania krajowego mechanizmu prewencji tortur są wykonywane przez kilka instytucji lub organizacji. W każdym z tych modeli państwo strona ma obowiązek zagwarantowania funkcjonalnej niezależności mechanizmu (art. 18 OPCAT).

$\mathrm{W}$ art. 19 OPCAT zawarto minimalne uprawnienia, które powinien posiadać krajowy mechanizm prewencji tortur. Przede wszystkim musi mieć możliwość regularnego sprawdzania sposobu traktowania osób pozbawionych wolności, przedstawiania rekomendacji właściwym władzom, w celu poprawy traktowania tych osób czy też możliwość przedstawiania propozycji i uwag odnośnie do obowiązujących i projektowanych przepisów prawnych.

38 http://www.apt.ch/en/npm-models/ (dostęp: 7.05.2018); E. Dawidziuk, Dwa lata działalności Krajowego Mechanizmu Prewencji w Polsce — wyniki wizytacji jednostek oraz placówek dla nieletnich, „Przegląd Więziennictwa Polskiego” 2010, nr 69, s. 144-145.

Nowa Kodyfikacja Prawa Karnego 54, 2019

(C) for this edition by CNS 
Rola krajowego mechanizmu prewencji tortur nie powinna się ograniczać tylko do formułowania rekomendacji, ale powinna polegać również na aktywnym monitorowaniu tego, jak te rekomendacje są wdrażane $^{39}$, a także na podejmowaniu działań na przykład o charakterze edukacyjnym $^{40}$. W systemie zapobiegania torturom stworzonym przez OPCAT mechanizm krajowy ma uzupełniać działania podejmowane przez Podkomitet do spraw Prewencji Tortur, a także na bieżąco identyfikować czynniki zwiększające wystąpienie ryzyka tortur czy innego złego traktowania ${ }^{41}$.

Rzeczpospolita Polska stosunkowo szybko przystąpiła do OPCAT. Na podstawie uprzedniej zgody wyrażonej w ustawie ${ }^{42} 14$ września 2005 roku Polska ratyfikowała Protokół fakultatywny do Konwencji w sprawie zakazu stosowania tortur oraz innego okrutnego, nieludzkiego lub poniżającego traktowania albo karania ${ }^{43}$. Po upływie 30 dni od przystąpienia do Protokołu dwudziestego państwa strony ${ }^{44}$ wszedł on w życie 22 września 2006 roku również w stosunku do Polski ${ }^{45}$.

39 M.D. Evans, C. Haenni-Dale, op. cit., s. 51.

${ }^{40}$ E. Steinerte, The Jewel in the crown and its three guardians. Independence of National Preventive Mechanisms under the Optional Protocol to the UN Torture Convention, „Human Rights Law Review” 14, 2014, z. 1, s. 6.

41 M.D. Evans, C. Haenni-Dale, op. cit., s. 54; oraz E. Steinerte, op. cit., s. 6.

42 Ustawa z dnia 5 lipca 2005 roku o ratyfikacji Protokołu fakultatywnego do Konwencji w sprawie zakazu stosowania tortur oraz innego okrutnego, nieludzkiego lub poniżającego traktowania albo karania, przyjętego przez Zgromadzenie Ogólne Narodów Zjednoczonych w Nowym Jorku w dniu 18 grudnia 2002 roku (Dz.U. z 2005 r. Nr 150, poz. 1253).

43 Protokół fakultatywny do Konwencji w sprawie zakazu stosowania tortur oraz innego okrutnego, nieludzkiego lub poniżającego traktowania albo karania, przyjęty przez Zgromadzenie Ogólne Narodów Zjednoczonych w Nowym Jorku dnia 18 grudnia 2002 roku (Dz.U. z 2007 r. Nr 30, poz. 192).

44 Art. 28 OPCAT.

45 Oświadczenie rządowe z dnia 23 czerwca 2006 roku w sprawie mocy obowiązującej Protokołu fakultatywnego do Konwencji w sprawie zakazu stosowania tortur oraz innego okrutnego, nieludzkiego lub poniżającego traktowania albo karania, przyjętego przez Zgromadzenie Ogólne Narodów Zjednoczonych w Nowym Jorku dnia 18 grudnia 2002 roku (Dz.U. z 2007 r. Nr 30, poz. 193).

Nowa Kodyfikacja Prawa Karnego 54, 2019

(C) for this edition by CNS 
Ustawa ratyfikująca OPCAT została przyjęta przez Sejm i Senat bez poprawek ${ }^{46}$. Wszystkie kluby parlamentarne Sejmu IV kadencji ${ }^{47}$ poparly ratyfikację przez Polskę Protokołu fakultatywnego ${ }^{48}$. Sposób wypełnienia przez Polskę zobowiązań nałożonych przez Protokół nie był przedmiotem dyskusji w toku prac nad ustawą w Sejmie, bo parlamentarzyści poparli stanowisko rządu, który w uzasadnieniu projektu ustawy o ratyfikacji OPCAT przewidywał, że funkcje Krajowego Mechanizmu Prewencji Tortur będzie wypełniał Rzecznik Praw Obywatelskich ${ }^{49}$. Stworzenie Krajowego Mechanizmu Prewencji Tortur mimo rozmów prowadzonych między rządem a RPO nie nastąpiło szybko ${ }^{50}$. Oficjalnie powierzenie funkcji Krajowego Mechanizmu Prewencji Tortur Rzecznikowi Praw Obywatelskich miało miejsce 18 stycznia 2008 roku $^{51}$, czyli po upływie prawie czterech miesięcy od wyznaczonego w art. 17 OPCAT terminu. Resort sprawiedliwości wyraził pogląd, że nie jest konieczne wprowadzenie

46 Przebieg procesu legislacyjnego, druk sejmowy nr 4085 Sejm RP IV kadencji Rządowy projekt ustawy o ratyfikacji Protokołu Fakultatywnego do Konwencji w sprawie zakazu stosowania tortur oraz innego okrutnego, nieludzkiego lub poniżającego traktowania albo karania, przyjętego przez Zgromadzenie Ogólne Narodów Zjednoczonych w Nowym Jorku w dniu 18 grudnia 2002 roku, http://orka.sejm.gov.pl/proc4.nsf/opisy/4085.htm (dostęp: 20.07.2016).

${ }^{47} \mathrm{http}: / /$ www.Sejm.gov.pl/archiwum/kluby/kadencja4/kluby_kola.htm (dostęp: 20.07.2016).

${ }^{48}$ Sprawozdanie stenograficzne ze 107 Posiedzenia Sejmu RP IV kadencji w dniu 7 lipca 2005 roku, http://orka.sejm.gov.pl/StenoInter.nsf/0/E27D78D2D0A45935C125703 700812A66/\$file/107-cksiazka.pdf, s. 436 n.; Sprawozdanie stenograficzne ze 107 Posiedzenia Sejmu RP IV kadencji w dniu 8 lipca 2005 roku, http://orka.sejm.gov.pl/StenoInter.nsf/0/ FC648637D03590A0C125703C00404B99/\$file/107-dksiazka.pdf, s. 504; oraz Stenogram z posiedzenia Komisji Sprawiedliwości i Praw Człowieka oraz Komisji Spraw Zagranicznych z 30 czerwca 2005 roku, http://orka.sejm.gov.pl/Biuletyn.nsf/wgskrnr/SZA-259 (dostęp: 20.07.2016).

${ }^{49}$ Sprawozdanie stenograficzne ze 107 Posiedzenia Sejmu RP..., s. 436 n. oraz s. 504.

${ }^{50}$ M. Fajst, Ochrona praw osób uwięzionych w Polsce — systemy CPT i OPCAT, [w:] Przestrzeganie praw osób pozbawionych wolności. O monitoringu jednostek penitencjarnych, red. W. Klaus, M. Niełaczna, Warszawa 2008, s. 34.

${ }^{51}$ Pismo Podsekretarza Stanu w Ministerstwie Sprawiedliwości do Rzecznika Praw Obywatelskich z dnia 18 stycznia 2008 roku, sygn. DWM i 482/48/02 powierzające wykonywanie funkcji Krajowego Mechanizmu Prewencji Tortur Rzecznikowi Praw Obywatelskich, https://www.rpo.gov.pl/sites/default/files/1202829239.pdf (dostęp: 20.07.2016).

Nowa Kodyfikacja Prawa Karnego 54, 2019

(C) for this edition by CNS 
zmian legislacyjnych, a oszacowane wcześniej środki zostaną uwzględnione w budżecie RPO. Krajowy Mechanizm Prewencji Tortur przez ponad dwa lata od powołania funkcjonował jedynie na podstawie OPCAT i ustawy o Rzeczniku Praw Obywatelskich ${ }^{52}$. Zadania wynikające z Protokołu wykonywał głównie Zespół Prawa Karnego Wykonawczego, którego pracownicy równocześnie zajmowali się rozpatrywaniem wniosków obywateli kierowanych do RPO ${ }^{53}$. Takie umiejscowienie pełnienia zadań wynikających z OPCAT nie spełniało zaleceń Podkomitetu do spraw Prewencji Tortur ONZ i APT (ang. Association for the Prevention of Torture), według których pełnienie funkcji KMPT, jeśli jest powierzone istniejącej już instytucji, wykonującej inne funkcje, to wypełnianiem zadań wynikających z Protokołu powinien zajmować się w niej odrębny zespół pracowników dysponujący niezależnym budżetem ${ }^{54}$.

Dopiero 14 października 2010 roku Marszałek Sejmu zarządzeniem nr 7/2010 nadał nowy statut organizacyjny Biura Rzecznika Praw Obywatelskich (dalej: BRPO) i w ramach struktury organizacyjnej biura powstał zespół Krajowy Mechanizm Prewencji (dalej: KMP) ${ }^{55}$. Do grudnia 2016 roku była to jedyna oficjalna nazwa tej komórki organizacyjnej

52 Ustawa z dnia 15 lipca 1987 roku o Rzeczniku Praw Obywatelskich, Dz.U. Nr 21, poz. 123 z późn. zm.

53 Raport Rzecznika Praw Obywatelskich z działalności w Polsce Krajowego Mechanizmu Prewencji w roku 2010, Biuletyn RPO 2011, nr 3. „Źródła”, red. S. Trociuk, Warszawa 2011, s. 9-10, https:/www.rpo.gov.pl/sites/default/files/BIULETYN_RZECZNIKA_PRAW_OBYWATELSKICH_2011_nr_3.pdf (dostęp: 14.06.2018).

${ }^{54}$ First annual report of the Subcommittee on Prevention of Torture and Other Cruel, Inhuman or Degrading Treatment or Punishment, February 2007 to March 2008, Genewa 2008, s. 10, https://digitallibrary.un.org/record/627322/files/CAT_C_40_2-EN. pdf (dostęp: 14.06.2018); Guidelines on national preventive mechanisms, Subcommittee on Prevention of Torture and Other Cruel, Inhuman or Degrading Treatment or Punishment Twelfth Session, Geneva 15-17 November 2010, CAT/OP/12/5: http://docstore. ohchr.org/SelfServices/FilesHandler.ashx?enc=6QkG1d\%2fPPRiCAqhKb7yhsquBlBC PFD\%2bXLNadyD9hiZ4SGqsp7QTyjY12aNwfqi3CFkvYEqp\%2bUSHT\%2fCEAk5s aRSeK0Q8FOnukzOhJMO2O6T\%2frttROW5qBoyJYZCbh7io7 (dostęp: 14.06.2018); oraz Przewodnik..., s. 33 n.

55 Zarządzenie Marszałka Sejmu nr 7/2010 z dnia 14 października 2010 roku w sprawie nadania statutu Biuru Rzecznika Praw Obywatelskich; oraz załącznik do zarządzenia nr 7 Marszałka Sejmu z dnia 14 października 2010 roku Statut Biura Rzecznika Praw Obywatelskich.

Nowa Kodyfikacja Prawa Karnego 54, 2019

(C) for this edition by CNS 
Biura Rzecznika Praw Obywatelskich. Nazwa ta, będąca thumaczeniem angielskiego zwrotu użytego w tekście Protokołu (National Preventive Mechanism), nie nawiązywała do celów działania Mechanizmu. Innymi słowy, nie wiadomo było, czemu Mechanizm miałby zapobiegać. Już teraz warto zauważyć, że niektórzy badani również mieli problemy ze sprecyzowaniem zadań instytucji określanej skrótem KMP. Inaczej niż w Polsce w części państw, które utworzyły krajowe mechanizmy, słowo „tortury” zostało włączone do oficjalnej nazwy instytucji ${ }^{56}$.

Uregulowanie zasad funkcjonowania KMPT i zapewnienia niezależności funkcjonalnej jego personelu na poziomie statutu BRPO, nie realizowało zaleceń dotyczących tworzenia KMPT i uregulowania ich mandatu w ustawie ${ }^{57}$. Niedostateczną autonomię KMPT w ramach struktury BRPO podkreślali również prawnicy działający w Porozumieniu na rzecz wprowadzenia $\mathrm{OPCAT}^{58}$.

W efekcie nacisków społecznych 18 sierpnia 2011 roku Sejm RP przyjął senacki projekt ustawy o zmianie ustawy z 15 lipca 1987 roku o Rzeczniku Praw Obywatelskich. Nowelizacja ustawy wprowadziła przepisy dotyczące pełnienia przez RPO funkcji Krajowego Mechanizmu Prewencji Tortur ${ }^{59}$, które w naszej ocenie są niewystarczające, ponieważ nie realizują zaleceń SPT dotyczących umocowania mandatu KMPT w odrębnej ustawie lub konstytucji ${ }^{60}$.

W październiku 2016 roku decyzją Rzecznika Praw Obywatelskich została powołana Komisja Ekspertów Krajowego Mechanizmu Prewen-

56 Np. w Paragwaju hiszp. Mecanismo Nacional de Prevención de la Tortura, zob. http://www.mnp.gov.py/ (dostęp: 12.02.2019) czy w Szwajcarii niem. Nationale Kommission zur Verhütung von Folter, zob. https:/www.nkvf.admin.ch/nkvf/de/home.html (dostęp: 12.02.2019).

57 Przewodnik..., s. 33 n.

58 M. Fajst, op. cit., s. 34-39. Porozumienie na rzecz wprowadzenia OPCAT powstało w październiku 2007 roku w jego skład weszli przedstawiciele środowiska akademickiego i organizacji pozarządowych. Celem tej koalicji była między innymi pomoc w stworzeniu i organizacji Krajowego Mechanizmu Prewencji Tortur oraz udział w wykonywaniu jego funkcji i zadań. Zob. https://watch.interwencjaprawna.pl/koalicja.html (dostęp: 30.12.2018).

59 Ustawa z dnia 18 sierpnia 2011 roku o zmianie ustawy o Rzeczniku Praw Obywatelskich, Dz.U. z 2011 r. Nr 222, poz. 1320.

60 Guidelines on national preventive mechanisms, s. 7.

Nowa Kodyfikacja Prawa Karnego 54, 2019

(C) for this edition by CNS 
cji Tortur. W jej skład weszli przedstawiciele środowiska akademickiego, służb mundurowych, organizacji pozarządowych oraz lekarze i prawnicy. Działalność Komisji Ekspertów KMPT ma służyć wsparciu bieżących działań Mechanizmu, jak opiniowanie aktów prawnych, konsultowanie opracowanych przez KMPT raportów tematycznych i wypracowaniu długofalowej strategii działania Krajowego Mechanizmu Prewencji Tortur. Na skutek presji Komisji Ekspertów KMPT Rzecznik Praw Obywatelskich w grudniu 2016 roku wyraził zgodę na posługiwanie się przez Zespół w BRPO wykonujący zadania wynikające z OPCAT nazwami: „Krajowy Mechanizm Prewencji Tortur” lub „Krajowy Mechanizm Prewencji Tortur, Okrutnego, Nieludzkiego i Poniżającego Traktowania oraz Karania"61.

Według stanu na dzień 30 września 2019 roku Zespół wizytujący Krajowego Mechanizmu Prewencji Tortur składa się z jedenastu członków ${ }^{62}$. Są to: prawnicy, politolodzy, psycholodzy, kryminolodzy i socjolodzy, którzy podczas przeprowadzania wizytacji są wspierani przez zewnętrznych ekspertów głównie z zakresu medycyny oraz zajmujących się problematyką osób niepełnosprawnych i cudzoziemców. Podczas przeprowadzania wizytacji pracowników KMPT wspierają również pracownicy biur pełnomocników terenowych RPO z Gdańska, Wrocławia i Katowic ${ }^{63}$. Od 2016 roku w wizytacjach zakładów karnych i aresztów

61 https://rpo.gov.pl/pl/content/posiedzenie-rady-ekspertow-krajowego-me chanizmu-prewencji-kmp (dostęp: 3.03.2018); https://rpo.gov.pl/pl/content/komisja-ekspertow-kmpt (dostęp: 14.06.2018); Raport Rzecznika Praw Obywatelskich z działalności w Polsce Krajowego Mechanizmu Prewencji w roku 2016, Biuletyn RPO 2017, nr 4. „Źródła”, red. A. Iwanowska et al., Warszawa 2017, s. 11, https://www.rpo.gov.pl/sites/ default/files/Raport\%20Krajowego\%20Mechanizmu\%20Prewencji\%20Tortur\%20w\%20 2016\%20r..pdf (dostęp: 14.06.2018); Sprawozdanie z działalności Komisji Ekspertów Krajowego Mechanizmu Prewencji Tortur w roku 2016, oprac. A. Iwanowska), https://www. rpo.gov.pl/sites/default/files/Raport\%20Komisji\%20Ekspertow\%20KMPT\%20za\%20 rok\%202016.pdf (dostęp: 14.06.2018).

62 https:/www.rpo.gov.pl/pl/kmp/sklad-zespolu (dostęp: 6.10.2019).

63 Raport Rzecznika Praw Obywatelskich z działalności w Polsce Krajowego Mechanizmu Prewencji Tortur w 2018 r., s. 6, https:/www.rpo.gov.pl/sites/default/files/ KMPT\%20-\%20raport\%20za\%20rok\%202018.pdf (dostęp: 28.10.2019).

Nowa Kodyfikacja Prawa Karnego 54, 2019

(C) for this edition by CNS 
śledczych uczestniczą pracownicy Wydziału do spraw Żołnierzy i Funkcjonariuszy w $\mathrm{BRPO}^{64}$.

\section{Wyniki badań empirycznych}

Wprowadzenie w czyn idei systematycznych wizytacji więzień stało się możliwe w znacznym stopniu dzięki położeniu nacisku na twórczą współpracę i dialog jako alternatywy dla bezdusznej kontroli i atmosfery konfrontacji. Rozmowa partnerów (wizytujących i wizytowanych) o trudnościach była wskazywana jako skuteczniejszy instrument poprawy sytuacji niż wytykanie błędów i napiętnowanie. Idea prewencji, czyli badanie zgodności praktyki penitencjarnej ze standardami i pozytywne myślenie o przyszłości, w miejsce reaktywnego wskazywania błędów i pociągania do odpowiedzialności winnych naruszeń, okazała się skutecznym instrumentem łagodzenia opozycji. Jednak prawdopodobnie najsilniej na zmianę nastawienia przeciwników wpłynęło ustalenie, że wszelkie kontakty między instytucjami wizytującymi a władzami państwowymi oraz ustalenia poczynione w miejscach pozbawienia wolności będą miały charakter poufny. To w jakimś stopniu stępiło ostrze zarzutu, że idea OPCAT godzi w zasadę suwerenności państw i niezależność systemów sprawiedliwości karnej.

Aby te szczytne idee mogły znaleźć odzwierciedlenie w praktyce konieczne było spełnienie jeszcze dwóch warunków. Po pierwsze, potrzebne było pełne zrozumienie przez władze państw członkowskich filozofii OPCAT oraz idąca za tym gotowość współpracy służb więziennych i policyjnych z instytucjami wizytującymi. Po drugie, należało zbudować zaufanie między podmiotami wizytującymi a instytucjami wizytowanymi. To zaś było możliwe dzięki temu, że osoby zaangażowane $\mathrm{w}$ taką aktywność miały spełniać najwyższe standardy zawodowe i etyczne, to znaczy miały się charakteryzować najwyższym poziomem wiedzy profesjonalnej i cieszyć niekwestionowanym autorytetem. Przepisy OPCAT,

${ }^{64}$ Raport Rzecznika Praw Obywatelskich z działalności w Polsce Krajowego Mechanizmu Prewencji w roku 2017, Biuletyn RPO 2018, nr 4. „Źródła”, red. H. Machińska, A. Jędrzejczyk, P. Kazimirski, Warszawa 2018, s. 15-17.

Nowa Kodyfikacja Prawa Karnego 54, 2019

(C) for this edition by CNS 
wzmocnione postanowieniami Zasad Paryskich ${ }^{65}$ nie pozostawiają w tej kwestii żadnych wątpliwości — osoby wizytujące muszą być wybitnymi ekspertami o wysokim poziomie niezależności.

I właśnie tego dotyczyły prezentowane tu badania. Ich celem było poznanie opinii funkcjonariuszy Służby Więziennej z wybranych więzień na temat funkcjonowania Krajowego Mechanizmu Prewencji Tortur w Polsce. Zgodnie z wymaganiami triangulacji metod badawczych ${ }^{66}$ zastosowaliśmy dwie metody badawcze. Po pierwsze, przeprowadziliśmy typowe badania ankietowe w dwóch wariantach: w formie ankiety środowiskowej oraz ankiety audytoryjnej (badania ilościowe). Po drugie, serię wywiadów pogłębionych (badania jakościowe).

W pierwszym wypadku respondenci zwracali wypełnione ankiety do specjalnie przygotowanej urny ${ }^{67}$, a w drugim wypełniali je funkcjonariusze odbywający szkolenie w jednym z ośrodków szkoleniowych Służby Więziennej. Zakładamy, że zastosowanie tych dwóch technik zwiększyło poczucie anonimowości respondentów. W związku z tym, że antycypowaliśmy różny poziom wiedzy respondentów w ankiecie zostały zastosowane pytania filtrujące.

Druga zastosowana metoda to wywiad częściowo standaryzowany ${ }^{68}$ przeprowadzony na podstawie przewodnika do wywiadu. Sięgnięcie po ten instrument gromadzenia danych pozwoliło na zadanie respondentom pytań, podobnych do tych które znalazły się w ankiecie oraz takich, których nie można było włączyć do kwestionariusza.

Taka procedura badawcza pozwalała weryfikować uzyskane dane i gwarantowała wyższy poziom trafności wyników ${ }^{69}$.

65 Rezolucja Zgromadzenia Ogólnego ONZ 48/134 1993. Regulują działalność krajowych instytucji prawno-człowieczych. Tekst dokumentu w języku angielskim: https:/www.ohchr.org/EN/ProfessionalInterest/Pages/StatusOfNationalInstitutions.aspx (dostęp: 16.10.2019).

66 A. Sułek, Sondaż Polski. Przygarść rozpraw o badaniach ankietowych, Warszawa 2007, s. 27.

67 J. Sztumski, Wstęp do metod i technik badań społecznych, Katowice 2005, s. $172-173$.

68 Ibidem, s. 160.

69 Ch. Frankfort-Nachmias, D. Nachmias, Metody badawcze w naukach społecznych, przeł. E. Hornowska, Poznań 2001, s. 222-223.

Nowa Kodyfikacja Prawa Karnego 54, 2019

(C) for this edition by CNS 
Zarówno w ankiecie, jak i w przewodniku do wywiadu znalazły się następujące bloki tematyczne: wiedza na temat Krajowego Mechanizmu Prewencji Tortur; opinia o przebiegu wizytacji i pracownikach KMPT; opinia o zaleceniach formułowanych dla więzień; opinia o potrzebie wizytacji i funkcjonowaniu KMPT oraz metryczka.

Sposób doboru próby do badań można określić jako dobór wielostopniowy ${ }^{70}$. Pierwszy etap polegał na stworzeniu listy więzień, które były wizytowane przez Krajowy Mechanizm Prewencji Tortur od czasu jego utworzenia w 2008 roku do 6 września 2017 roku$^{71}$. Z dostępnych danych wynikało, że jednostki penitencjarne (zakłady karne, areszty śledcze i oddziały zewnętrzne) były wizytowane raz, dwa lub trzy razy. Wyjątkiem był Zakład Karny w Płocku, który był wizytowany cztery razy i który z oczywistych powodów został włączony do badań.

Na podstawie wykazu jednostek penitencjarnych ${ }^{72}$ oraz zestawienia wizytacji KMPT wyłoniliśmy te zakłady karne i areszty śledcze, które nie były wizytowane oraz te, które były.

$\mathrm{W}$ ten sposób powstały cztery grupy jednostek penitencjarnych: 1. wizytowane areszty śledcze, 2 . wizytowane zakłady karne, 3 . wizytowane oddziały zewnętrzne, 4. zakłady karne i areszty śledcze, które nie były wizytowane. W drodze losowania wyłoniliśmy po jednej palcówce penitencjarnej z każdej grupy — Areszt Śledczy w Warszawie-Białołęce (areszt śledczy wizytowany dwa razy), Zakład Karny w Wojkowicach (zakład karny wizytowany jeden raz), Oddział Zewnętrzny Aresztu Śledczego w Olsztynie (oddział zewnętrzny wizytowany raz), Zakład Karny w Głubczycach (więzienie, które nie było wizytowane). Jako piąty do próby został włączony wspominany wcześniej Zakład Karny w Płocku.

W celu uzupełnienia materiału empirycznego przeprowadziliśmy badania ankietowe wśród funkcjonariuszy odbywających szkolenie na

70 R. Mayntz, K. Holm, P. Hübner, Wprowadzenie do metod socjologii empirycznej, przeł. W. Lipnik, Warszawa 1985, s. 104-105.

${ }^{71}$ Listę opracowaliśmy na podstawie wyszukiwarki wizytacji znajdującej się na stronie internetowej Rzecznika Praw Obywatelskich, https://www.rpo.gov.pl/pl/content/ wizytacje-krajowego-mechanizmu-prewencji (dostęp: 19.01.2018), oraz raportów rocznych z działalności Krajowego Mechanizmu Prewencji.

72 Obwieszczenie Ministra Sprawiedliwości z dnia 1 sierpnia 2016 roku w sprawie wykazu jednostek organizacyjnych podległych Ministrowi Sprawiedliwości lub przez niego nadzorowanych, M.P. z dnia 19 sierpnia 2016 roku, poz. 801.

Nowa Kodyfikacja Prawa Karnego 54, 2019

(C) for this edition by CNS 
pierwszy stopień podoficerski w Ośrodku Szkolenia Służby Więziennej w Kulach. Tutaj badaniami zostali objęci wszyscy funkcjonariusze odbywający szkolenie (badanie miało formę ankiety audytoryjnej).

I wreszcie przeprowadziliśmy wywiady pogłębione z kilkunastoma funkcjonariuszami Służby Więziennej dobranymi w sposób celowy. Chodziło o to, aby przeprowadzić rozmowy z kierownikami działów ochrony i działu penitencjarnego, ale także z wychowawcami i strażnikami. Funkcjonariusze i pracownicy działów kwatermistrzowskiego i służby zdrowia nie byli zainteresowani udziałem w badaniach.

Badania zostały przeprowadzone w okresie od października do grudnia 2017 roku.

Zgodnie z założeniami w każdej jednostce penitencjarnej mieliśmy przeprowadzić badania na próbie 25 wylosowanych osób. Wszystkie ankiety wręczaliśmy osobiście, a respondenci zwracali je do zapieczętowanej urny, co miało zwiększyć u nich poczucie anonimowości. Ponieważ nie w każdym więzieniu udało się rozdać 25 ankiet, w AŚ w Białołęce i ZK w Wojkowicach rozdaliśmy po 30 ankiet.

Jak już była mowa w ramach badań przeprowadziliśmy ankietę audytoryjną wśród słuchaczy kursu w jednym z ośrodków szkoleniowych Służby Więziennej. W badaniach wzięło udział 58 funkcjonariuszy ( 58 zwrotów).

W ten sposób łącznie rozdaliśmy 187 ankiet, a otrzymaliśmy 132. Liczby rozdanych i zwróconych ankiet ilustruje poniższa tabela.

Tabela 1. Liczba zwróconych ankiet

\begin{tabular}{|l|c|c|c|c|c|c|c|}
\hline & $\begin{array}{c}\text { AŚ } \\
\text { Białołęka }\end{array}$ & $\begin{array}{c}\text { OZ AŚ } \\
\text { Olsztyn }\end{array}$ & $\begin{array}{c}\text { ZK } \\
\text { Głub- } \\
\text { czyce }\end{array}$ & $\begin{array}{c}\text { ZK } \\
\text { Płock }\end{array}$ & $\begin{array}{c}\text { ZK Woj- } \\
\text { kowice }\end{array}$ & $\begin{array}{c}\text { OSSW } \\
\text { Kule }\end{array}$ & Razem \\
\hline $\begin{array}{l}\text { liczba } \\
\text { rozdanych }\end{array}$ & 30 & 21 & 23 & 25 & 30 & 58 & 187 \\
\hline $\begin{array}{l}\text { liczba } \\
\text { zwróco- } \\
\text { nych }\end{array}$ & 10 & 9 & 19 & 13 & 23 & 58 & 132 \\
\hline $\begin{array}{l}\text { odsetek } \\
\text { zwrotów } \\
(\%)\end{array}$ & 33 & 43 & 83 & 52 & 77 & 100 & 71 \\
\hline
\end{tabular}

Źródło: opracowanie własne.

Nowa Kodyfikacja Prawa Karnego 54, 2019

(C) for this edition by CNS 
Warto jedynie zauważyć, że najwięcej zwrotów otrzymaliśmy w jednostce, która nie była wizytowana przez Krajowy Mechanizm Prewencji Tortur.

Na wywiad zgodziło się dwunastu funkcjonariuszy dwóch kluczowych działów — penitencjarnego i ochrony. Rozmowy trwały od około 10 do 40 minut.

\section{Analiza wyników ankiet. Charakterystyka respondentów}

Wśród respondentów przeważali mężczyźni (80\%), można zatem mówić o niewielkiej nadreprezentacji tej płci ${ }^{73}$.

Najwięcej badanych było w wieku od 26 do 35 lat. Stanowili oni ponad połowę wszystkich (68) respondentów. Natomiast w populacji funkcjonariuszy SW najliczniejsi są funkcjonariusze w wieku od 36 do $40 \mathrm{lat}^{74}$. Nadreprezentacja osób młodszych jest efektem ankiety audytoryjnej wśród funkcjonariuszy odbywających szkolenie na pierwszy stopień podoficerski.

Większość respondentów miało wykształcenie wyższe ( 88 badanych, czyli 67\%). Wśród wszystkich funkcjonariuszy Służby Więziennej osoby $\mathrm{z}$ wykształceniem wyższym też stanowią najliczniejszą grupę ${ }^{75}$.

Średni staż pracy/służby ankietowanych wyniósł nieco ponad 6 lat, a mediana 3 lata. Stażu pracy w więziennictwie nie ujawniło pięciu respondentów. Najliczniejszą grupą wśród badanych byli respondenci pracujący do pięciu lat (było ich 65 to jest 49\% wszystkich badanych). Najdłużej pracujący badany zadeklarował, że pracuje od 27 lat. Wśród ogółu funkcjonariuszy najliczniejsi są też ci ze stażem pracy od 5 do 9 lat $^{76}$.

Badani najczęściej byli zatrudnieni w dziale ochrony $(65 \%)$ i dziale penitencjarnym $(12 \%)$. Wśród ankietowanych byli też pracownicy działów kwatermistrzowskiego, finansowego, organizacyjno-prawnego,

73 Wybrane zagadnienia statystyczne — grudzień 2017, s. 12, http:/www.sw.gov. pl/strona/statystyka--biezaca (dostęp: 20.01.2018).

74 Ibidem.

75 Ibidem.

76 Ibidem.

Nowa Kodyfikacja Prawa Karnego 54, 2019

(C) for this edition by CNS 
kadr, służby zdrowia. Tak ukształtowana próba w zasadzie odzwierciedlała strukturę zawodową Służby Więziennej ${ }^{77}$.

\section{Wiedza respondentów \\ o Krajowym Mechanizmie Prewencji Tortur}

$\mathrm{Na}$ wstępie należy wyjaśnić, że we wszystkich narzędziach badawczych występowała nazwa tradycyjna, czyli Krajowy Mechanizm Prewencji, bo to ona kształtowała świadomość funkcjonariuszy. Jak już wspomniano, słowo „tortury” zostało dodane stosunkowo niedawno.

Pytania zamieszczone w pierwszej części kwestionariusza ankiety dotyczyły wiedzy respondentów na temat Krajowego Mechanizmu Prewencji. Na pierwsze pytanie o to, czy respondenci słyszeli o tej instytucji, twierdząco odpowiedziało 27 osób (20\%).

To raczej niewiele, biorąc pod uwagę fakt, że w próbie przeważały jednostki wizytowane przez KMPT. Pewne światło na ten niepokojący fakt rzuciły przeprowadzone wywiady. W kilku wypadkach rozmówcy początkowo nie kojarzyli nazwy Krajowy Mechanizm Prewencji. Sytuacja zmieniała się dopiero po wyjaśnieniu, że chodzi o zespół w Biurze Rzecznika Praw Obywatelskich. Jeden z rozmówców ujmuje to tak: „W pierwszym momencie nie skojarzyłem tego z Rzecznikiem, nazwę słyszałem, ale my się tutaj w rozmowach posługujemy, że to Rzecznik kontrola Rzecznika" (W9 - wywiad numer 9).

Warto też odnotować, że dwaj ankietowani przyznali, że wprawdzie wiedzą, co to za instytucja, ale ich wiedza na ten temat jest ograniczona. Respondent, któremu nadaliśmy numer 101, stwierdza: „Posiadam zbyt małą wiedzę w tym temacie", natomiast inny usprawiedliwia swoją niewiedzę tym, że „brak solidnych szkoleń” (ankieta nr 309).

Uprawnionym wydawało się, przypuszczenie, że wiedza respondentów na temat KMP będzie zależała od tego, czy dana jednostka była wizytowana i ile razy. Okazało się jednak, że wcale nie musi tak być. Więzieniem, w którym więcej respondentów wskazało na odpowiedź „TAK” był OZ AŚ w Olsztynie ${ }^{78}$, wizytowane tylko raz i to kilka lat wcześniej.

77 Polska Stużba Więzienna, Warszawa 2010, s. 13.

78 Jednostka wizytowana raz w 2011 roku.

Nowa Kodyfikacja Prawa Karnego 54, 2019

(C) for this edition by CNS 
W pozostałych czterech więzieniach przeważali ci ankietowani, którzy o KMPT nie słyszeli. Było tak również w jednostkach kilkakrotnie wizytowanych, na przykład w AŚ Białołęka i ZK Płock. Może to oczywiście wynikać z tego, że ci, którzy słyszeli o KMPT, nie zdecydowali się na zwrot ankiet.

Po zestawieniu odpowiedzi na to zasadnicze pytanie ze stażem pracy w SW trzeba stwierdzić, że nie rysują się tu żadne szczególnie oczywiste zależności. Poza jedną, a mianowicie obserwacją, że niemal wszyscy respondenci pracujący $\mathrm{w}$ więziennictwie stosunkowo długo (15-20 lat) słyszeli o KMPT (sześć na siedem osób w tym przedziale stażu służby). Jednak przy tak niewielkich liczbach trudno wyciągać daleko idące wnioski.

Wszystkich ankietowanych niezależnie od tego, czy słyszeli o Krajowym Mechanizmie Prewencji, czy nie, poprosiliśmy, aby napisali, z czym kojarzy im się ta nazwa. Treść odpowiedzi pozostawiliśmy inwencji respondentów. Na to pytanie odpowiedziało 91 badanych, przy czym niektórzy podali więcej niż jedno skojarzenie. Wszystkie one dają się podzielić na jedenaście kategorii przedstawionych na wykresie.

Już na pierwszy rzut oka zwraca uwagę fakt, że u większości ankietowanych nazwa Krajowy Mechanizm Prewencji nie wywołuje żadnych skojarzeń (22 odpowiedzi), co przy obecności słowa „prewencja” w nazwie może dziwić. To, że były to osoby, które przyznały, że nie słyszały o KMP, niczego nie thumaczy. Problem jest chyba poważny i tu nie chodzi tylko o językową sprawność respondentów, ale o ich ogólną orientację $\mathrm{w}$ instytucjonalnym otoczeniu więziennictwa, bo jednak KMP funkcjonuje w przestrzeni publicznej od lat. Ale sprawa ma także zupełnie inny wymiar, a mianowicie każe postawić pytanie o to, jaki wizerunek tej ważnej instytucji został wykreowany przez Biuro Rzecznika Praw Obywatelskich oraz przez samych członków Zespołu KMP? Do tej kwestii przyjdzie nam jeszcze wrócić.

Drugim najczęściej wskazywanym skojarzeniem (niezależnie od tego, czy respondent słyszał o KMP, czy nie) była prewencja lub zapobieganie czemuś bez doprecyzowania czemu dokładnie (21 odpowiedzi). Znacząco mniej licznej grupie respondentów nazwa Krajowy Mechanizm Prewencji kojarzyła się z zapobieganiem przestępczości (12 odpowiedzi), a jeszcze mniejszej z Policją (7 odpowiedzi). Mamy poważne

Nowa Kodyfikacja Prawa Karnego 54, 2019

(C) for this edition by CNS 


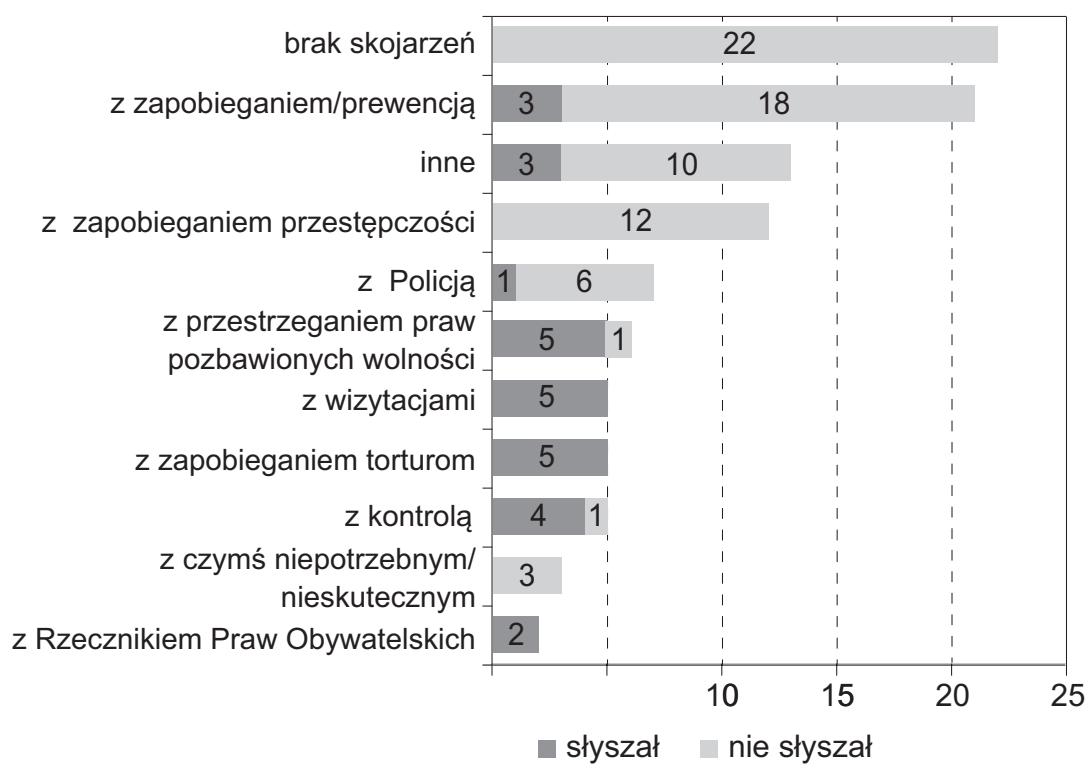

Wykres 1. Skojarzenia respondentów dotyczące Krajowego Mechanizmu Prewencji

Źródło: opracowanie własne na podstawie odpowiedzi ankietowanych na pytania nr 1 i $21^{80}$.

powody przypuszczać, że ankietowani, którzy nigdy wcześniej nie słyszeli o omawianej instytucji, zwrócili uwagę na słowo „prewencja”, kojarzące im się ze służbą prewencji Policji ${ }^{80}$. Odnotujmy, że w jednym przypadku akronim KMP skojarzył się respondentowi także $\mathrm{z}$ tą formacją, ale z komendą miejską Policji (ankieta nr 421).

Jedna respondentka, która nigdy wcześniej nie słyszała o Krajowym Mechanizmie Prewencji, powiązała tę nazwę z przestrzeganiem praw osób pozbawionych wolności ${ }^{81}$.

79 Odpowiedź respondenta 111, który nie odpowiedział tylko na jedno pytanie, a na pozostałe udzielił merytorycznych odpowiedzi, zaliczyliśmy do kategorii „słyszał”, trzech pozostałych respondentów $(116,526,530)$, którzy odpowiedzieli tylko na pytanie 21 i pytania metryczkowe, zaliczyliśmy do kategorii „nie słyszał”.

${ }^{80} \mathrm{http}$ ://www.policja.pl/pol/kgp/biuro-prewencji/wydzial-prewencji/zadania-wydzialu/125605,Zadania-Wydzialu-Prewencji.html (dostęp: 23.01.2018).

81 Ankieta nr 104. „KMP kojarzy mi się z prewencyjnymi działaniami dotyczącymi sposobu odbywania kary, traktowania osadzonych".

Nowa Kodyfikacja Prawa Karnego 54, 2019

(C) for this edition by CNS 
Wobec tych danych można zasadnie twierdzić, że skojarzenia badanych, którzy pierwszy raz zetknęli się z nazwą Krajowy Mechanizm Prewencji, prawie wcale nie odnosiły się do rzeczywistych zadań i celu funkcjonowania tej instytucji. Dlatego tak ważne jest, aby posługiwać się nazwą Krajowy Mechanizm Prewencji Tortur, która jasno wskazuje, po co ta instytucja istnieje - jakie jest jej naczelne zadanie.

Wśród 21 respondentów, którzy słyszeli o Krajowym Mechanizmie Prewencji i odpowiedzieli na to pytanie jednakowo, często pojawiało się skojarzenie z przestrzeganiem praw pozbawionych wolności, z wizytacjami, z zapobieganiem torturom czy z kontrolą (4-5 wyborów). Na Rzecznika Praw Obywatelskich jako swoje skojarzenie z Krajowym Mechanizmem Prewencji wskazało dwóch badanych. To także znamienny fakt.

Pytanie $\mathrm{nr} 2 \mathrm{w}$ ankiecie dotyczyło źródeł wiedzy respondenta na temat Krajowego Mechanizmu Prewencji. Pytanie miało formę pytania półotwartego, z kafeterią koniunktywną. Odpowiadali na nie tylko ci badani, którzy zadeklarowali, że słyszeli o KMP, a jak się okazuje, najliczniejsi byli ci, którzy wiedzę o tej instytucji czerpali z mediów obejmujących prasę, radio, telewizję i internet (11 wskazań). Po 7 wskazań „otrzymali" przełożeni badanych, czyli dyrektorzy jednostek penitencjarnych oraz kierownicy działów. Nieco mniej, bo 5 razy, badani wskazali, że źródłem ich wiedzy byli inni funkcjonariusze, i pracownicy więziennictwa oraz wykładowcy szkoleń służbowych. Nie bez satysfakcji odnotowujemy, że jedna respondentka wymieniła studia podyplomowe organizowane w Instytucie Profilaktyki Społecznej i Resocjalizacji UW ${ }^{82}$.

$\mathrm{W}$ trzecim pytaniu zadaniem respondenta było dokończenie wypowiedzi: „Krajowy Mechanizm Prewencji (KMP) zajmuje się...”. Spośród 25 odpowiedzi należało wyeliminować dwie zupełnie błędne ${ }^{83}$, natomiast pozostali respondenci najczęściej wskazywali na zadania, które wiążą się mandatem KMP: „zakaz stosowania tortur oraz innego nieludzkiego traktowania” (ankieta nr 113), ,przeprowadzanie wizytacji miejsc odosobnienia” (ankieta nr 112), „kontrolę pracy funkcjonariuszy i warunków w więzieniu” (ankieta nr 528), „ochronę praw człowieka, w szczególności praw osadzonych" (ankieta nr 303).

82 Twórcą i wieloletnim kierownikiem tych studiów był Zbigniew Lasocik.

83 Ankieta nr 204, odpowiedź: „Niebieska Karta” i ankieta nr 545, odpowiedź „,badaniem prewencyjnych działań służb”.

Nowa Kodyfikacja Prawa Karnego 54, 2019

(C) for this edition by CNS 
Odnotujmy, że siedmiu ankietowanych (5\% wszystkich) wskazało na zadania KMP wynikające art. 19 pkt 1 OPCAT, czyli: „wizytowanie i monitorowanie miejsc, w których przebywają osoby pozbawione wolności” (ankieta nr 205) czy „sprawdzanie traktowania osób pozbawionych wolności" (ankieta nr 114). O publikacji rocznego raportu z wizytacji napisało trzech badanych, a dwóch respondentów wskazało, że KMPT zajmuje się przedstawianiem uwag do obowiązujących oraz projektowanych przepisów prawnych. Żaden z respondentów nie wymienił zadania określonego w art. 19 pkt 2 OPCAT, czyli przedstawiania rekomendacji właściwym władzom w celu poprawy traktowania osób pozbawionych wolności i zapobiegania torturom.

W kolejnym pytaniu respondenci zostali poproszeni o wskazanie organizacji międzynarodowej, z którą wiąże się działanie Krajowego Mechanizmu Prewencji. Na to pytanie odpowiedziało 30 badanych, natomiast poprawnej odpowiedzi, wskazując ONZ udzieliło 12 osób. Niemal identyczna była liczba respondentów (11), którzy nie wiedzieli, z jaką organizacją powiązać KMP. Do swoistego folkloru intelektualnego zaliczamy pojedyncze odpowiedzi sugerujące, że Krajowy Mechanizm Prewencji należy łączyć z Unią Europejską, Radą Europy i Organizacją Bezpieczeństwa i Współpracy w Europie. Jeśli chodzi o działy Służby Więziennej, poprawnej odpowiedzi zdecydowanie częściej udzielali funkcjonariusze działu penitencjarnego niż działu ochrony, jednak liczby nie pozwalają na wyciąganie jakichkolwiek wniosków, może poza jednym — że warto tę kwestię zbadać bardziej szczegółowo.

Na pytanie: „Czy wie Pani/Pan, jaka instytucja pełni funkcję Krajowego Mechanizmu Prewencji (KMP)?”, poprawnie odpowiedziało 20 spośród 21 respondentów, którzy zadeklarowali, że znają odpowiedź. Odnotujmy jedynie dla porządku, że 18 osób z tej kategorii legitymuje się wykształceniem wyższym magisterskim.

W kolejnym pytaniu badani mieli odpowiedzieć, czy jednostka, w której obecnie pracują, była kiedyś wizytowana przez Krajowy Mechanizm Prewencji. Na to pytanie odpowiedziały 23 osoby spośród 74 ankietowanych w więzieniach (z wyłączeniem uczestników kursu podoficerskiego). Aby nie wchodzić w szczegóły, powiedzmy jedynie, że wśród badanych byli zarówno ci, którzy wiedzieli, że ich jednostka macierzysta była wizytowana, jak i ci, którzy tego nie wiedzieli. W wypadku zakładu 
karnego, który nie był wizytowany, tylko jeden z sześciu respondentów potwierdził ten fakt, pozostali nie znali prawidłowej odpowiedzi. Najciekawszy okazał się przypadek ZK Płock, wizytowanego cztery razy. Spośród pięciu badanych, którzy odpowiedzieli na to pytanie, dwóch odpowiedziało, że jednostka była wizytowana, trzech natomiast, że nie wie, czy tak było. Także w tym wypadku liczebności każą zachować powściągliwość w interpretacji, jednak naturalne jest pytanie, jak to się dzieje, że funkcjonariusz jednostki penitencjarnej, która była wizytowana cztery razy, nie jest tego świadom. Niewątpliwie jest to kwestia przepływu informacji w ramach administracji więziennej, ale także rangi wizyty KMP w miejscu pozbawienia wolności. Z własnego doświadczenia wiem, że w trakcie wizyt Podkomitetu do spraw Prewencji Tortur ONZ wszyscy funkcjonariusze, z którymi się stykaliśmy, doskonale wiedzieli, kim jesteśmy i jaki jest cel naszej wizyty.

Próba zdekodowania opinii funkcjonariuszy SW na temat działania KMP okazała się zadaniem trudnym przede wszystkim ze względu na znikomą wiedzę respondentów na ten temat. W drodze kolejnych etapów „filtrowania” respondentów ustaliliśmy, że w próbie znalazło się 12 respondentów, którzy byli obecni w czasie trwania wizyty KMP i sformułowali stosowne opinie. Tylko te nieliczne wypowiedzi mogliśmy brać pod uwagę.

Kluczowe dla tej kwestii pytanie miało formę tabeli z sześcioma stwierdzeniami dotyczącymi opinii na temat przedstawicieli KMP. Natomiast dla oceny stopnia akceptacji zaproponowanych przez nas twierdzeń zastosowaliśmy klasyczną pięciostopniową skalę Likerta ${ }^{84}$ (,zdecydowanie się zgadzam”; „raczej się zgadzam”; „raczej się nie zgadzam”; „zdecydowanie się nie zgadzam” oraz „nie wiem/trudno powiedzieć”). Odpowiedzi respondentów na to pytanie ankiety przedstawia wykres.

Z pierwszym stwierdzeniem: „Przedstawicie Krajowego Mechanizmu Prewencji mają wystarczającą wiedzę na temat funkcjonowania więzienia" nie zgodziła się połowa (6) respondentów, a czterech wybrało odpowiedź ,nie wiem/trudno powiedzieć”.

84 E. Babbie, Badania społeczne w praktyce, przeł. W. Betkiewicz et al., red. A. Kloskowska-Dudzińska,Warszawa 2004, s. 191-192.

Nowa Kodyfikacja Prawa Karnego 54, 2019

(C) for this edition by CNS 
Odpowiedzi ankietowanych na pytanie 9

- Zdecydowanie się nie zgadzam

- Nie wiem / trudno mi powiedzieć

Zdecydowanie się zgadzam
Raczej się nie zgadzam

- Raczej się zgadzam

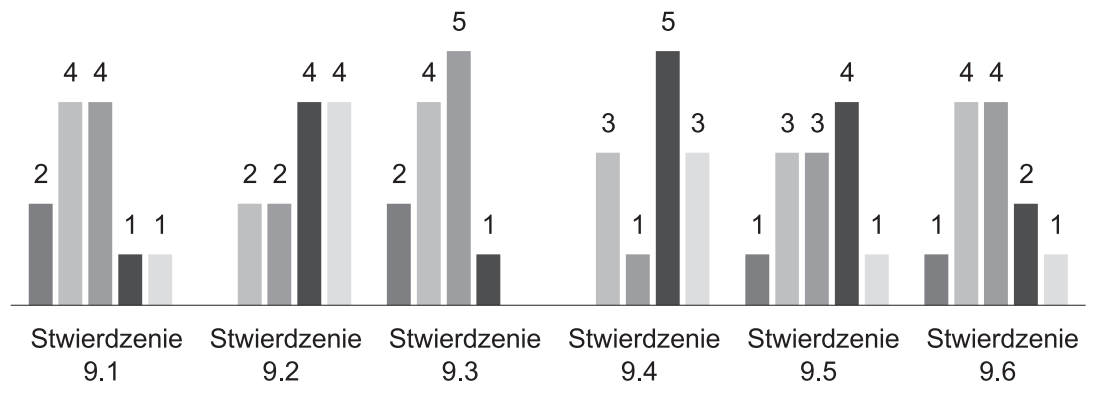

Wykres 2. Opinie ankietowanych o przedstawicielach Krajowego Mechanizmu Prewencji Tortur

Źródło: opracowanie własne.

Kolejne stwierdzenie brzmiało: „Przedstawiciele Krajowego Mechanizmu Prewencji podczas wizytacji skupiają się tylko na poszukiwaniu naruszeń i nieprawidłowości”. W tym przypadku ośmiu respondentów zgodziło się z tym twierdzeniem (,zdecydowanie” i ,raczej tak”), co może oznaczać, że eksperci KMP wizytujący jednostki penitencjarne poszukują jedynie naruszeń prawa, a nie dostrzegają tego, co działa prawidłowo. Natomiast dwóch ankietowanych wskazało na odpowiedź „,nie wiem/trudno powiedzieć".

Ze stwierdzeniem: „Przedstawiciele Krajowego Mechanizmu mają doświadczenie w kontaktach z więźniami” nie zgodziło się sześciu respondentów (,zdecydowanie” i ,raczej tak”). Żaden z ankietowanych nie wskazał odpowiedzi „zdecydowanie się zgadzam”, a pięciu wybrało odpowiedź: „nie wiem/trudno powiedzieć”. Można chyba twierdzić, że ankietowani raczej krytycznie ocenili doświadczenia członków KMP w kontaktach z więźniami lub uchylili się od oceny.

W kolejnym stwierdzeniu odnieśliśmy się do formułowanego czasem przekonania, że „Przedstawiciele Krajowego Mechanizmu Prewen- 
cji podczas przeprowadzania wizytacji zaburzają porządek dnia w wizytowanej jednostce”. Zgodziła się z tym sądem (,zdecydowanie” i „,raczej tak") większość respondentów (8). Tym razem tylko jeden respondent wybrał odpowiedź „nie wiem/trudno powiedzieć”.

Następne stwierdzenie brzmiało tak: „Przedstawiciele Krajowego Mechanizmu Prewencji weryfikują podczas wizytacji informacje, które uzyskali od więźniów". Opinie respondentów rozłożyły się stosunkowo równomiernie, bo pięciu z nich było bardziej skłonnych zgodzić się z tym stwierdzeniem, a czterech się z nim nie zgodziło.

W stwierdzeniu: „Przedstawiciele Krajowego Mechanizmu Prewencji wspierają więzienników w realizacji zaleceń powizytacyjnych" nawiązywaliśmy do idei dialogu, leżącej u podstaw OPCAT. Jeśli pięciu respondentów się z nim nie zgodziło, a czterech wskazało na odpowiedź: „nie wiem/trudno powiedzieć”, to można zasadnie twierdzić, że funkcjonariusze raczej nie czują wsparcia ze strony ekspertów KMP. Ta kwestia jest zbyt ważna, aby poprzestać na tej bardzo wstępnej, ale także słabo udokumentowanej konstatacji.

Następna część ankiety była poświęcona rekomendacjom formułowanym przez KMP dla więzień. Pierwsze pytanie miało na celu sprawdzenie, czy respondenci znają zalecenia sformułowane dla jednostki, w której pracują i czy postrzegają je jako coś ważnego. Spośród dziewięciu ankietowanych, którzy odpowiedzieli na to pytanie, czterech wskazało odpowiedź: „tak, bo to istotny dokument”. Dwóch badanych wskazało odpowiedź: „tak, ale nie ma tam nic ważnego”, a dwóch ,inne możliwości, proszę napisać jakie”. Jeden ankietowany wskazał odpowiedź: „nie, bo nie miałem możliwości zapoznania się".

Gdzie indziej pytaliśmy, czy zdaniem respondentów to, co rekomenduje KMPT, jest możliwe do wprowadzenia w ich jednostce. Spośród badanych, którzy w pytaniu zadeklarowali, że zapoznali się z zaleceniami, wszyscy wskazali, że tylko część z nich można wprowadzić w jednostce, w której pracują. Jeden z respondentów, który wybrał odpowiedź: „Tak, ale nie wszystkie”, tak uzasadnił swoje zdanie: „Ponieważ niektóre są absurdalne nie oparte na przepisach funkcjonujących w Polsce" (ankieta nr 606).

Kolejne pytanie ankiety dotyczyło tego, czy respondenci postrzegają rekomendacje KMP jako wypracowane po konsultacji z administracją więzienną, czy też jako narzucone im w trybie dalekim od dialogu. Tu

Nowa Kodyfikacja Prawa Karnego 54, 2019

(C) for this edition by CNS 
liczebności były jeszcze mniejsze, zatem nie będziemy analizować tego wątku poza stwierdzeniem, że opinie były podzielone, bo badani w równych proporcjach odpowiadali „tak”, „nie”, „nie wiem”.

Na pytanie o to, czy istnieje potrzeba wprowadzenia zmian w funkcjonowaniu KMP odpowiedziało 33 respondentów, przy czym większość ankietowanych (18) wskazała odpowiedź ,nie wiem/nie mam zdania”. Jest to odpowiedź tyleż zaskakująca, co zrozumiała. Zaskakująca, bo w wielu rozmowach funkcjonariusze SW wyrażali negatywne oceny KMP, zatem powinni mieć wyrobione zdanie w tej materii. Zrozumiała, bo jeśli wiedza respondentów o KMP jest niewielka, o czym już była mowa, to trudno oczekiwać, aby mieli wyrobione zdanie na ten temat. A nawet jeśli mają, to paramilitarny charakter formacji nie musi sprzyjać gotowości do prezentowania go nawet w anonimowej ankiecie.

Jedynie trzech badanych wskazało na potrzebę wprowadzenia zmian w KMPT, z czego dwie osoby wymieniły konkretne problemy, które należy rozwiązać, aby Krajowy Mechanizm Prewencji pełnił swoją funkcję. Jedna $z$ nich wymieniła zbyt mocną koncentrację KMP na skazanych, bez uwzględniania realiów pracy SW, a druga brak doświadczenia praktycznego pracowników KMP przeprowadzających wizytacje. Warto przy tej okazji odnotować, że w uwagach ogólnych jeden z respondentów wyraził podobny pogląd, pisząc: „Uważam, że jednostki organizacyjne więziennictwa powinny być wizytowane przez bardziej doświadczone osoby, tj. np. byłych f-szy Służby Więziennej” (ankieta nr 112). Trudno się zgodzić z tym poglądem, ale sama idea wydaje się słuszna.

Na pytanie, czy wizytacje KMP są potrzebne, odpowiedziało 30 ankietowanych, przy czym 9 respondentów udzieliło odpowiedzi twierdzącej, a 9 było odmiennego zdania. Swoistą ciekawostką może być fakt, że najwięcej zwolenników pochodziło z jednostki, która nie była wizytowana, natomiast żaden z respondentów z Zakładu Karnego w Płocku, który był wizytowany cztery razy, nie uznał tej formy aktywności KMP za potrzebną. Jeśli chodzi o uzasadnienie celowości wizyt, trudno wyciągać jakiekolwiek wnioski, bo respondenci ograniczali się do zdawkowych sformułowań, że to może pomóc w funkcjonowaniu więzień. Wśród uzasadnień odpowiedzi negatywnej najczęściej pojawiał się argument, że Służba Więzienna działa zgodnie z przepisami i nie ma potrzeby jej kontrolować. Tym bardziej że w ramach SW już istnieją instytucje kontrolujące pracę funkcjonariuszy.

Nowa Kodyfikacja Prawa Karnego 54, 2019

(C) for this edition by CNS 
Na podstawie zgromadzonego materiału badawczego można zasadnie twierdzić, że wiedza ankietowanych funkcjonariuszy SW na temat Krajowego Mechanizmu Prewencji jest skromna, mimo że ta instytucja funkcjonuje w Polsce już od ponad 10 lat. Badani, którzy słyszeli o KMP, łączyli tę instytucję z ochroną praw pozbawionych wolności, ale rzadziej wspominali o zapobieganiu torturom. Dlatego z uznaniem należy przyjąć decyzję Rzecznika Praw Obywatelskich o wprowadzeniu słowa „tortury" do nazwy Mechanizmu. Będzie to miało na pewno walor edukacyjny.

Istnieją też podstawy, aby sądzić, że w części respondenci utożsamiali Krajowy Mechanizm Prewencji Tortur z Rzecznikiem Praw Obywatelskich i „tradycyjnymi” zadaniami tego urzędu, czyli reakcją na skargi kierowane do Biura RPO. O ile badani wiedzą o KMPT, o tyle wiedzę na ten temat czerpią w pierwszej kolejności z mediów.

Jeśli chodzi o opinie respondentów na temat Krajowego Mechanizmu Prewencji Tortur, to w wypowiedziach przebija raczej negatywny niż pozytywny ton. Jednak w wyciąganiu wniosków należy zachować daleko idącą powściągliwość, ponieważ zastosowane w ankiecie filtry sprawily, że liczba osób, które wypowiedziały się na ten temat, była stosunkowo niewielka.

Badani postrzegają ekspertów KMPT jako ludzi, którym brak nieco doświadczenia w wizytowaniu zakładów karnych. Wizyty te są przez respondentów odbierane jako coś, co zaburza funkcjonowanie więzienia, natomiast $\mathrm{w}$ trakcie realizacji swoich zadań osoby wizytujące koncentrują się na poszukiwaniu naruszeń i nieprawidłowości w funkcjonowaniu jednostek, a nie pozytywów.

To dlatego zalecenia formułowane przez KMPT nie są postrzegane przez więzienników jako coś istotnego.

\section{Analiza treści wywiadów}

Jak już była o tym mowa, uzupełnieniem materiału badawczego pochodzącego $\mathrm{z}$ ankiet była treść wywiadów przeprowadzonych z 12 funkcjonariuszami SW pracującymi w jednostkach penitencjarnych wizytowanych przez KMP. Siedmiu badanych było z działu penitencjarnego a pięciu $z$ działu ochrony ${ }^{85}$. W próbie znalazły się dwie kobiety pracujące

85 Nikt z działu kwatermistrzowskiego i ze służby zdrowia nie zgodził się na rozmowę.

Nowa Kodyfikacja Prawa Karnego 54, 2019

(C) for this edition by CNS 
jako wychowawczynie. Staż pracy respondentów w Służbie Więziennej wynosił od roku do 26 lat, co gwarantowało zróżnicowanie doświadczeń i wyższą wartość poznawczą wyników ${ }^{86}$.

W przewodniku do wywiadu znalazły się następujące zagadnienia: wiedza respondentów o Krajowym Mechanizmie Prewencji ${ }^{87}$, opinia o przebiegu wizytacji, opinia na temat pracowników Krajowego Mechanizmu Prewencji Tortur, opinia o zaleceniach formułowanych dla jednostek, w których badani pracują, opinia o samej instytucji — potrzebie prowadzenia wizytacji i wprowadzeniu w niej ewentualnych zmian.

Spośród respondentów dwóch nie słyszało wcześniej o KMP — byli to strażnicy pracujący w dziale ochrony od 5 lat. Wprawdzie na koniec rozmowy jeden z nich wspomniał, że słyszał o prewencji tortur na studiach przy okazji omawiania konwencji ONZ, do których Polska przystąpiła, jednak nie potrafił powiedzieć nic więcej na ten temat. W tym zakresie wynik wywiadów pokrywa się z wynikami badań ankietowych.

Pozostałych dziesięciu rozmówców zetknęło się z nazwą Krajowy Mechanizm Prewencji, chociaż trzech z nich początkowo nie wiedziało, o czym mowa. Jeden z nich wyjaśnił, że „w pierwszym momencie nie skojarzyłem tego z Rzecznikiem, nazwę słyszałem, ale my się tutaj w rozmowach posługujemy, że to Rzecznik - kontrola Rzecznika" (W9). Inni rozmówcy też często używali terminu „Rzecznik” na określenie działań prowadzonych przez Krajowy Mechanizm Prewencji Tortur.

To, że funkcjonariusze posługują się określeniem „Rzecznik”, wynika przede wszystkim z tego, że to Rzecznik Praw Obywatelskich pełni funkcję Mechanizmu, a Zespół KMP jest strukturalnie ulokowany w Biurze RPO. Dla wielu osób RPO jest synonimem niezależności i autorytetu. O czym wspominali niektórzy respondenci: ,rzecznik jest niezawisły no i dostał to z tego tytułu. On wydaje takie opinie [...]. To, co [...] powie, czy da tą opinię, to gdzieś to ma wzięcie” (W2). „Zdanie RPO jest poważnie traktowane" (W9).

86 A.N. Oppenheim, Kwestionariusze, wywiady, pomiary postaw, przeł. S. Amsterdamski, Poznań 2004, s. 86; M. Theiss, Metody zbierania danych - wywiady socjologiczne, [w:] B. Szatur-Jaworska, Ewaluacja w stużbach społecznych, Warszawa 2010, s. 122.

${ }^{87} \mathrm{~W}$ narzędziach badawczych posługiwaliśmy się jedyną nazwą zespołu obowiązującą w latach 2008-2016 — „Krajowy Mechanizm Prewencji”.

Nowa Kodyfikacja Prawa Karnego 54, 2019

(C) for this edition by CNS 
Natomiast nazwa Krajowy Mechanizm Prewencji bez dodatkowego członu „Tortur” jest niezrozumiała: „nie wiem, dlaczego się tak nazwali. Ta nazwa nic nie mówi, czym oni się zajmują i ja od początku, jak o tym słyszałem, tego nie wiem, dlaczego tak [...] po tym szkoleniu o KMP rozmawiałem, tak $\mathrm{w}$ rodzinie $\mathrm{z}$ różnymi osobami prywatnie to ta nazwa Krajowy Mechanizm Prewencji to się ten „mechanizm” komuś z maszyną kojarzył” (W3). ,Jak pierwszy raz to usłyszałam, to nie wiedziałam, czym to się zajmuje po samej nazwie. Dopiero po wythumaczeniu" (W8). „Kojarzy mi się z zapobieganiem, ale ta nazwa Krajowy Mechanizm Prewencji to nic nie mówi” (W12). Dlatego też określenie „Rzecznik” było tak popularne, bo miało konkretny desygnat.

Rozmówcy, którzy zetknęli się już wcześniej z Krajowym Mechanizmem Prewencji najczęściej mówili o zapobieganiu przestępczości, a akronim KMP kojarzyli z Policją (komenda miejska Policji). Respondent określony jako W1 mówi tak: „no jakieś przeciwdziałania, zapobiegania powiedzmy różnym jakimś przejawom, powiedzmy popełnianiu przestępstw. To zależy też jaka prewencja... No słyszałem też, w policji jest prewencja" (W1). I kilka innych wypowiedzi: „ta prewencja, to może się różnie kojarzyć. No przede wszystkim to policja, tam jest wydział prewencji i oni się zajmują zapewnieniem bezpieczeństwa, porządku. Tutaj ta prewencja to nie wiem, co oni widzieli w tym" (W3); ,prewencja to zapobieganie czemuś. No pewnie, jeśli chodzi o zakłady karne, to będzie zapobieganie powrotu do przestępczości, no tak mi się wydaje” (W4); „ta nazwa, sam skrót KMP to mi się tylko z jednym kojarzy — Komenda Miejska Policji” (W5); ,skojarzenia: prewencja to policja” (W8); „w Policji jest prewencja” (W12).

Jeden z badanych, który pierwszy raz zetknął się z nazwą KMP, łączył ją $z$ informowaniem funkcjonariuszy $i$ skazanych o przepisach prawnych: „może, w sumie... to nie wiem, może chodzi o coś takiego, że jakieś informowanie... broszury... pisma informacyjne wysyłane tutaj, żeby nie wiem... osadzonych jak i funkcjonariuszy uświadamiać odnośnie stanu prawnego... próbuje to jakoś na chłopski rozum rozgryźć" (W6). Inny z rozmówców wskazał, że chodzi o zakaz stosowania tortur i nieludzkiego traktowania: ,znaczy, no wiadomo konkretnie, że oni się zajmują zakazem tortur, nieludzkiego traktowania” (W2).

Warto zaznaczyć, że dwóch badanych uważało, że należy posługiwać się nazwą, która określa cel działania Mechanizmu: „Kojarzy mi się

Nowa Kodyfikacja Prawa Karnego 54, 2019

(C) for this edition by CNS 
z zapobieganiem, ale ta nazwa Krajowy Mechanizm Prewencji to nic nie mówi. Ja bym tam jeszcze parę słów dopisał: Krajowy Mechanizm Prewencji Znęcania się nad Osobami Pozbawionymi Wolności, o tak to by było wiadomo” (W12). Natomiast drugi z respondentów powiedział: „no to tak jak z CPT, to wtedy by było nawet lepiej chyba. Bo ta nazwa KMP to nic nie mówi też tak dla ludzi ze społeczeństwa, nawet nie tutaj w więzieniu, ale tak w ogóle. Nie wiadomo, po co oni są. Bo nazwa też jest ważna, np. Straż Pożarna to wiadomo gasi pożar czy Rzecznik Praw Obywatelskich zajmuje się prawami obywateli, wiadomo od czego jest" (W3).

Jeśli chodzi o zadania Krajowego Mechanizmu Prewencji Tortur, badani najczęściej wymieniali wizytacje więzień, sprawdzanie tego, jak traktowani są pozbawieni wolności i ewentualnie formułowanie rekomendacji. Respondenci najczęściej wiązali KMP z wizytacją więzień, natomiast nie wspominali, że Mechanizm wizytuje też inne miejsca, w których przebywają osoby pozbawione wolności: „tak, zajmują się humanitarnym traktowaniem więźniów, wizytują jednostki” (W8), „no chyba tylko po więzieniach jeżdżą" (W12).

Jeden z respondentów zwrócił uwagę, że jego zdaniem z raportów Krajowego Mechanizmu Prewencji Tortur niewiele wynika, uważał, że Rzecznik Praw Obywatelskich może na coś wpłynąć, a KMPT raczej nie. Stwierdził też, że jego zdaniem więźniowie nie widzą w Mechanizmie „,instytucji, która może im pomóc”.

Rozmówcy wskazywali najczęściej, że o KMP dowiedzieli się z mediów lub w trakcie odpraw z kierownictwem. Rzadziej wspominali o szkoleniach organizowanych przez więziennictwo. Dwaj respondenci, kierownicy działu penitencjarnego i działu ochrony, dowiedzieli się z korespondencji oficjalnej zakładu karnego. Jeden z badanych wskazał, że o KMPT usłyszał na spotkaniu z RPO i zastępcą dyrektora KMPT w więzieniu, w którym pracuje. Temat Krajowego Mechanizmu Prewencji jest sporadycznie poruszany w trakcie rozmów między funkcjonariuszami.

O ile badani łączą Krajowy Mechanizm Prewencji Tortur Rzecznikiem Praw Obywatelskich, o tyle zupełnie pomijają Organizację Narodów Zjednoczonych. Jeśli już pojawia się jakaś instytucja międzynarodowa, jest nią Unia Europejska: ,to pewnie unijny twór, pewnie jest też zagranicą” (W9) albo: „to chyba przyszło jak do UE weszliśmy” (W12). ,Jest też w innych państwach, ale czy to unijne czy jakaś inna organizacja, to nie wiem" (W11).

Nowa Kodyfikacja Prawa Karnego 54, 2019

(C) for this edition by CNS 
Niektórzy z badanych nie wiedzieli, czy więzienie, w którym pracują, było wizytowane przez KMP. Świadczą o tym takie wypowiedzi: „O Jezus... No jakieś kontrole to były, ale czy to akurat $\mathrm{z}$ tego to trudno powiedzieć” (W4) albo: „No wiem, że są wizytacje przez nich robione, ale nie kojarzę, czy byli u nas w jednostce. Ja się nigdy osobiście z nimi nie spotkałam” (W5). Ci, którzy wiedzieli najczęściej nie znali szczegółów: „Coś tam kojarzę, że kilka lat temu była wizytacja” (W3); „,byli, ale nie pamiętam dokładnie, kiedy to było i ile razy” (W7); „tak, osobiście się zetknąłem jednokrotnie, ale mogło być więcej” (W9).

Takie sformułowania pozwalają sądzić, że wizytacja KMP nie była traktowana jako ważne wydarzenie, o którym trzeba pamiętać. Jeden z badanych ujmuje to dość jednoznacznie: „to była jedna z wielu kontroli, wizytacji, które mamy tutaj i nie wiem, czy czymś się wyróżniała od innych" (W9).

Respondentów, którzy wiedzieli, czy ich jednostka była wizytowana, pytaliśmy o przypuszczenia, dlaczego akurat ta placówka została wybrana. Badani najczęściej uważali, że Krajowy Mechanizm Prewencji wizytuje te zakłady karne i areszty śledcze, w których skazani piszą dużo skarg: ,wydaje mi się, że wiadomo, że oni też interwencyjnie pewnie gdzieś jeżdżą. Nie wiem, wiąże się to ze skargami osadzonych czy jakimiś ich wnioskami” (W2); „na początku to myślałem, że oni losowo wybierają, gdzie jadą. Ale też może oni zbierają jakieś donosy czy z CPT czy od Rzecznika, że coś tam się może dziać i wtedy typują — tam jechać” (W3); ,po prostu po jednostkach jeździli, osadzeni może pisali i dlatego” (W11); „[więzienie, w którym pracuję - Z.L. i A.M.] jest dla najgorszych osadzonych, trudnych przywożą tu. Oni piszą skarg najwięcej. Pewno chodzi o pozwy, tego typu sprawy i dlatego przyjechali” (W12). Zatem badani identyfikują misję KMP poprzez główne zadanie RPO, zupełnie ignorując rzecz najważniejszą, a mianowicie prewencyjny cel wizytacji.

Najczęściej nie mieli okazji poznać tego celu, bo nie rozmawiali z pracownikami KMP, którzy rozmawiają raczej z kierownictwem: „u nas to jest tak, że jak była jakaś wizytacja, czy to KMP, czy CPT to oni raczej z kierownictwem rozmawiają, nie tak jak tutaj ze mną wychowawcą na pierwszej linii frontu. Ze mną to nikt od nich nie rozmawiał jak była ta wizytacja" (W3). Jeszcze bardziej dotyczy to funkcjonariuszy działu ochrony: ,raczej nie [rozmawiali z Służbą Więzienną — Z.L. i A.M.] ktoś z administracji, czy kierownictwa z nimi chodził. Predzej z wychowawcami gadali. Raczej Nowa Kodyfikacja Prawa Karnego 54, 2019

(C) for this edition by CNS 
z ochroną nie gadali” (W11); ,wiem, że rozmawiali z więźniami, mogły być też rozmowy z funkcjonariuszami, ja nie uczestniczyłem” (W9).

W wypowiedziach respondentów tak jak w ankietach pojawiały się twierdzenia, że członkowie KMP wysłuchują jedynie więźniów, nie biorą pod uwagę zdania Służby Więziennej: „oni nie do końca są obiektywni w tym, co robią, słuchają tylko więźniów” (W8); „oni biorą to, co mówi osadzony, za pewnik, nie weryfikują tego” (W12); „słyszałem, jak to w innych jednostkach wygląda, rozmawiamy czasem o tym. Jakby to powiedzieć, oni są tacy bardzo pro dla osadzonych" (W4).

Respondenci mówili też o tym, że wizytujący nie zawsze byli dobrze przygotowani do wizytacji. Mogą o tym świadczyć następujące wypowiedzi: ,jak u nas byli, to nie mieli podstawowej wiedzy na temat funkcjonowania więzienia [...]. Powinni najpierw jeździć po więzieniach, żeby zapoznać, jak funkcjonuje więzienie” (W7); „byli zdziwieni tym, jak wygląda więzienie. Dziwiło ich, że są zalecenia, że niektórych więźniów trzeba kontrolować po wyjściu i po powrocie. Że u niektórych kontroli podlega ciało, a u innych nie. Jak się dowiedzieli, że jest taka procedura, to przyjęli, ale dopytywali się, dlaczego tak” (W11); „oni nie znają rzeczywistości więziennej. Nie znają rzeczywistości i przepisów, były tarcia” (W10); ,takie głosy przyszły mi w tej chwili do głowy, żeby się bardziej znali na funkcjonowaniu więzień, jak kontrolują i się nie znają, to piszą głupoty" (W3). Nawet jeśli te negatywne oceny są w jakimś zakresie przesadzone, to i tak nie wolno ich lekceważyć, bo są echem nie zawsze prawidłowego „klimatu” wizytacji KMP i braku partnerstwa między ekspertami a funkcjonariuszami SW.

Jednak nie zawsze tak musi być. Czasem atmosfera jest bardzo poprawna, a współpraca obopólnie korzystna: „pytają funkcjonariuszy o funkcjonowanie działów. Tłumaczą im codzienne funkcjonowanie jednostki. Mogą mieć też inne spostrzeżenia niż my. Dajemy im przekaz, co ma być robione [...]. Mają też do tego zrozumienie dla nas, co mówimy im o funkcjonowaniu zakładu karnego" (W7); ,zachowywali się normalnie, jak każdy, kto jest pierwszy raz. Myślę, że im więcej będą kontrolować, bo to chyba od niedawna jest... to będą więcej wiedzieć, jak praca SW jest ciężka z takimi osobami” (W11).

Jeśli chodzi o zalecenia formułowane przez KMPT, badani przyznawali, że znają je raczej w niewielkim zakresie: „coś tam kojarzę, że były

Nowa Kodyfikacja Prawa Karnego 54, 2019

(C) for this edition by CNS 
jakieś zalecenia. Nas to bardziej interesują te zalecenia CPT” (W3); „na pamięć ich nie znam, mogę je znaleźć. Przysłali je po wizytacji” (W7); „z tymi ich rekomendacjami to mnie nie zapoznali” (W8); „,nie znam szczegółowo, czy był po tej kontroli protokół. Wiem, że u nas byli” (W9); „coś przyszło, nie pamiętam dokładnie. Nie pamiętam tych wniosków” (W10); „nic o tym nie wiem. Nie wiem, co oni tam piszą raporty. Nie interesowałem się tym [...] chyba nie mieli uwag” (W11); ,nawet dokładnie tego nie czytałem. Pamiętam tylko że było o tym na odprawie, ale nie wiem dokładnie, czy to kierownik mówił w dziale, czy to na takiej ogólnej” (W12). Te cytaty nie wystawiają najlepszego świadectwa ich autorom, ale także mówią sporo o tym, jak postrzegane było KMP przez pracowników więzień.

Respondenci zwracali także uwagę na ,jakość” zaleceń i możliwość ich zrealizowania: „oni nie mają wyobrażenia na temat prowadzenia jednostki penitencjarnej, możliwości wprowadzenia pewnych rozwiązań. Więzienie ma pewien porządek. Ma zapewnić bezpieczeństwo i porządek wśród więźniów, osób, które tutaj pracują czy przychodzą na widzenia. [...] Różni się przecież półotwarty [zakład karny typu półotwartego Z.L. i A.M.] od zakładu dla recydywy. Oni mają w głowie taki obraz: "półotworek « [zakład karny typu półotwartego — Z.L. i A.M.] dla pierwszy raz karanych. Widzą "zamek « [zakład karny typu zamkniętego — Z.L. i A.M.] i to jest dla nich zderzenie. Nie mają doświadczenia, że są też różne więzienia. Powinni mieć styczność z zakładami, z praktyką” (W7). „Te zalecenia to są takie jakby to powiedzieć »teoretyczne « [...] Np. zalecenia dotyczące metrażu cel, że trzeba go zwiększyć, mniej skazanych osadzać w jednej celi. Tego się nie da tak po prostu zrealizować. W dużym więzieniu to nie ma na to funduszy. Żeby to zrealizować, to trzeba by kilka więzień jeszcze wybudować w Polsce. A to nie od nas zależy. [...] powinni dostosować zalecenia do konkretnej jednostki. To, co gdzieś funkcjonuje, nie zawsze będzie się dało wszędzie zastosować” (W3); „obsmarowali nas, że nie ma ciepłej wody w celach i żeby robić remonty. To niby jest możliwe do zrobienia, ale to są koszty" (W12). Jeden z badanych zwrócił też uwagę, że nie wie, czy zalecenia były konsultowane z dyrektorem więzienia: „trudno mi powiedzieć, czy to było konsultowane z Dyrektorem, dokonali inspekcji i przesłali ten raport" (W7). Skądinąd wiemy, że metodologia wizyty obejmuje stały kontakt z kierownictwem placówki. Respondent tego nie wiedział. Warto jednak postawić pytanie, czy to tylko jego „wina”.

Nowa Kodyfikacja Prawa Karnego 54, 2019

(C) for this edition by CNS 
Respondentów prosiliśmy o odpowiedź na pytanie, czy Krajowy Mechanizm Prewencji Tortur jest potrzebny. Sześciu badanych odpowiedziało, że tak, bo wizytatorzy niepracujący na co dzień w więzieniu mogą spojrzeć na pewne zachowania z innej perspektywy i coś doradzić: „każda komórka, która troszeczkę nadzoruje, czy jest w stanie podpowiedzieć, jak to naprawić, moim zdaniem jest potrzebna, tym bardziej że to są osoby, które może nie znają do końca funkcjonowania tak, jak my. Bo oni poza więzieniami, wiadomo, izby zatrzymań, izby wytrzeźwień i te inne rzeczy nadzorują, gdzie są przetrzymania w ogóle ludzi. No to oni mają na to patrzenie takie bardziej ludzkie i niektórzy może już pracując tyle lat za murami, to im się wydają niektóre rzeczy są normalne, a można popatrzeć. Oni przyjadą i popatrzą tak świeżo na to, czy to jest już nieludzkie traktowanie czy niegodne, czy też nie. Dobra, u nas może ktoś powiedzieć: skazany taki czy owaki, co na »ty« mu powiemy. To jest niby normalne, oni powiedzą: trzeba szacunek, trzeba godność i tak dalej. Jak oni przyjeżdżają, to mogą zobaczyć innym [wzrokiem Z.L. i A.M.] i mówię, wydać jakieś polecenie zmiany, czy coś nowego wprowadzić zmodyfikować. No to zawsze każde takie coś jest potrzebne, mnie się wydaje” (W2); „dobrze, że ktoś się będzie zajmował tym, jak prowadzić zmiany. Zawsze ich uwagi nowe pomysły, można wykorzystać do poprawy jednostki warunków osadzonym” (W7); „może po takiej wizytacji można wyciągnać wnioski i zmienić coś w systemie" (W11).

Zwolennicy działania Krajowego Mechanizmu Prewencji Tortur zwracali uwagę na to, że wizytacje mogą zapobiegać nadużyciom ze strony personelu instytucji zamkniętych i łamaniu praw człowieka: ,ja nie mówię, że wszyscy są święci, w SW też są psychole, co się znęcają [...]. Moim zdaniem to tak, jak mówił Stalin »kontrola jest podstawą zaufania«. Jest to potrzebne, żeby niektórym szajba nie odbiła [...], wiadomo, są prawa człowieka, to się każdemu należy” (W12). Albo tak: „to jest dobrze, że jest taka instytucja, czasami w takiej niedostępnej instytucji (ZK czy dom dziecka) może dojść do błędu. Szczególnie w małej, wtedy nie ma takiej kontroli wewnętrznej moim zdaniem. Jeżeli ktoś coś robi zgodnie z przepisami, nie przeszkadza mu osoba, która sprawdza, kontroluje. [...] Chodzi o to, żeby indywidualny przypadek nie był krzywdzony. Trzeba czuwać nad praworządnością" (W9). Wydaje się, że te dwie wypowiedzi dotykają istoty rzeczy. Ich autorzy w lapidarnej

Nowa Kodyfikacja Prawa Karnego 54, 2019

(C) for this edition by CNS 
formie ujęli wszystko to, co legło u podstaw OPCAT. Kluczowe pozostaje pytanie, w jakim stopniu takie osoby i takie postawy kształtują polski system penitencjarny.

Przeciwnicy działania Krajowego Mechanizmu Prewencji Tortur (cztery osoby) podnosili natomiast argument, że więzienia są wystarczająco intensywnie kontrolowane i kolejna instytucja „wtrącająca się w funkcjonowanie więzienia” nie jest już potrzebna: „myślę, że sam Rzecznik sobie radzi, jest też CPT. Tak obrazowo to wyjaśnię: jak jest Policja, to po co nam też Straż Miejska” (W3); „nie wiem [czy jest potrzebny — Z.L. i A.M.]. Osadzeni piszą, mają możliwość pisania do Rzecznika, wszystko jest uregulowane. Oni mają więcej praw, jak obowiązków, a i tak piszą. Mają możliwości kontrolowania tego, jakie są warunki odbywania kary, więc nie wiem, czy jest to potrzebne jeszcze, te wizytacje" (W5). Inny respondent wyraził pogląd, że wizytacje nie są potrzebne, gdyż obecnie w więzieniach w Polsce nie są stosowane tortury, a skazanych traktuje się w sposób humanitarny. „Nie jest to potrzebne nic im (więźniom) się źle nie dzieje. Lepiej mają jak w szpitalu. Kiedyś za PRL lata 70. to miało miejsce złe traktowanie, a teraz to nie. Teraz chodziła Pani po zakładzie to widziała, jak to wygląda. A oni to szukają jakiejś dziury. To dla więźniów ma być kara, nie może być tak, że osadzeni mają lepiej jak ludzie w szpitalu”. Osoba przeprowadzająca pyta: „czym dla Pana są tortury?”. Respondent odpowiada: „no znęcanie się nad człowiekiem, upadlanie. W więzieniu takich rzeczy nie ma. [...] My jesteśmy szkoleni, jak się mamy zachowywać. Jak słyszę o torturach, to mi się ...mam dosyć. Większą krzywdę by zrobił ktoś z telewizji czy z tych polityków, jakby ktoś ich tu do więzienia przyprowadził. My skazanym musimy zapewnić bezpieczeństwo od współosadzonych. Nikt tego, co tu robimy, nie dostrzega, tylko by krytykowali” (W4). Natomiast wychowawca, który jako jedyny spotkał się z pracownikiem KMP w czasie wizytacji, stwierdził, że działalność KMPT nie jest potrzebna w takiej formie jak obecnie, bo wizytatorzy słuchają jedynie więźniów i są negatywnie nastawieni do Służby Więziennej: ,irytujące było to, że jeżeli rozmawiali z tymczasowo aresztowanym, skazanym, odnosiło się wrażenie, że pozyskane informacje od więźniów były dla nich wykładnią. Funkcjonariusz był dla nich z założenia zły”. Osoba przeprowadzająca pyta: ,,a czy z Panem też rozmawiali?”. Respondent odpowiada: „tak, rozmawiał jeden ze mną [...]

Nowa Kodyfikacja Prawa Karnego 54, 2019

(C) for this edition by CNS 
ale to było takie, że ja jestem ten zły. Pamiętam, że miał pretensje o to, że nie zorganizuję zajęć K-O wspólnikom razem do jednej sprawy”. Osoba przeprowadzająca pyta: „czy uważa Pan, że KMP jest potrzebny?”. Respondent odpowiada: „nie wiem, czy to czemuś służy. W tej formie, jak oni tam to... raczej nie" (W10).

Zapytaliśmy funkcjonariuszy SW także o to, czy widzą potrzebę zmian w funkcjonowaniu KMP. Badani przyznawali, że zbyt mało wiedzą o tej instytucji, aby coś proponować. Jeśli pojawiały się jakikolwiek sugestie, to ich sens oddał respondent oznaczony jako W12: „żeby ci ludzie, którzy tam pracują, [...] popracowali chwilę z pozbawionymi wolności, tak jak ja tutaj na pierwszej linii”.

\section{Wnioski}

Spośród 132 funkcjonariuszy Służby Więziennej w zdecydowanej większości byli ci, którzy nie zetknęli się z nazwą Krajowy Mechanizm Prewencji. Jest to ustalenie zaskakujące, ponieważ w momencie badań ta instytucja działała w Polsce od 10 lat. Rzecz jasna nie wystawia to najlepszego świadectwa administracji penitencjarnej w Polsce, ale też każe zapytać, czy część odpowiedzialności nie spada na sam Mechanizm, a szerzej na Biuro Rzecznika Praw Obywatelskich? Aby jednak być w zgodzie z faktami, należy odnotować, że od momentu przeprowadzenia badań upłynął czas, który przyniósł kilka zasadniczych zmian w funkcjonowaniu KMPT. Zmiany te miały charakter organizacyjny i kadrowy. Wszystko zaczęło się od niezwykle ważnej decyzji rzecznika praw obywatelskich Adama Bodnara o zmianie nazwy polegającej na dodaniu słowa „tortury” do nazwy Mechanizmu. Funkcjonowanie tej instytucji otrzymało nowy, mocny impuls dzięki temu, że bezpośredni nadzór nad tym obszarem aktywności RPO objęła wybitna specjalistka w dziedzinie praw człowieka Hanna Machińska. Pracownicy Mechanizmu otrzymali także znaczące wsparcie ze strony Rady Ekspertów KMPT. To wszystko sprawia, że z dużym prawdopodobieństwem można zakładać, że podobne badania przeprowadzone dzisiaj przyniosłyby inne wyniki. Warto sprawdzić, jak bardzo inne.

Nazwa Krajowy Mechanizm Prewencji była dla tych osób niejasna. Jeśli próbowali ją kojarzyć z czymkolwiek, to najczęściej był to dział prewencji w Policji lub zapobieganie przestępczości.

Nowa Kodyfikacja Prawa Karnego 54, 2019

(C) for this edition by CNS 
Więziennicy, którzy słyszeli o Krajowym Mechanizmie Prewencji (zdecydowana mniejszość), wiedzieli, czym się zajmuje. Najczęściej też prawidłowo wskazywali instytucję pełniącą funkcję Mechanizmu w Polsce, czyli Rzecznika Praw Obywatelskich. Wystarczająco utożsamiali te dwie instytucje, że opisując prewencyjne wizyty Mechanizmu, posługiwali się sformułowaniem ,wizytacje Rzecznika”.

Eksperci KMP są przez funkcjonariuszy SW postrzegani przede wszystkim jako pracownicy Biura Rzecznika Praw Obywatelskich, a nie funkcjonującego w jego strukturze specjalnego zespołu zajmującego się prewencją tortur.

Badani sporadycznie wiązali Krajowy Mechanizm Prewencji z Organizacją Narodów Zjednoczonych. Wśród osób, z którymi przeprowadziliśmy wywiady, a które wykazały się nieco większa wiedzą na ten temat, nikt nie połączył tej instytucji z ONZ.

Jeśli chodzi o opinie respondentów o członkach KMP, najczęściej były one raczej negatywne lub neutralne. Przeważało przekonanie, że osoby wizytujące miejsca pozbawienia wolności nie są do tego dobrze przygotowane, ponieważ nie rozumieją zasad funkcjonowania takich miejsc, nie znają realiów więziennych, a także nie mają doświadczenia w kontaktach z osobami pozbawionymi wolności. Są nastawieni na ochronę więźniów, natomiast nie biorą pod uwagę sytuacji funkcjonariuszy SW. Wśród badanych były osoby, które dostrzegały korzyści płynące z wizytacji KMP, a także sugerowały, że członkowie tej instytucji mogą się wiele nauczyć w ich trakcie.

Rekomendacje Krajowego Mechanizmu Prewencji, które są kluczowym instrumentem oddziaływania tej instytucji, są mało znane respondentom. Ci, którzy wiedzieli na ten temat więcej, często formułowali wątpliwości, czy wszystkie zalecenia KMPT można zrealizować w takich warunkach, w jakich funkcjonują jednostki penitencjarne w Polsce. Niektóre z nich przekraczają możliwości konkretnego zakładu karnego, na przykład wymagają poważnych nakładów finansowych.

Jak już była o tym mowa wielokrotnie, konieczne jest posługiwanie się nazwą Krajowy Mechanizm Prewencji Tortur, bo to jasno określa zadanie tej instytucji. Jednocześnie Krajowy Mechanizm Prewencji Tortur powinien nadal intensywnie zaznaczać swoją obecność w życiu publicznym, a także podejmować działania mające na celu edukację społeczeństwa w kwestii tego, czym są tortury i czym jest im zapobieganie.

Nowa Kodyfikacja Prawa Karnego 54, 2019

(C) for this edition by CNS 
Przeprowadzone badania miały jedynie wstępny i przyczynkarski charakter. Natomiast zaprezentowane tu rozważania należy czytać, biorąc pod uwagę czas, który upłynął od ich przeprowadzenia, a także zasadnicze zmiany w funkcjonowaniu KMPT w ostatnich okresie. Rzetelność badawcza każe nam podkreślić, że uzyskane wyniki nie powinny być traktowane jako reprezentatywne, a przedstawione wnioski nie mogą być ekstrapolowane na cały system penitencjarny. To dlatego uważamy, że podobne badania powinny być prowadzone regularnie, być może na większą skalę oraz w innych instytucjach izolujących, które wizytuje Krajowy Mechanizm Prewencji Tortur.

\section{Bibliografia}

Babbie E., Badania spoteczne w praktyce, przeł. W. Betkiewicz et al., red. A. Kloskowska-Dudzińska, Warszawa 2004.

Balcerzak M., Podstawy międzynarodowej ochrony praw człowieka. Zarys wykładu z materiałami źródtowymi, Torun 2017.

Boeglin N., History of the Optional Protocol to the UN Convention against torture, [w:] N. Boeglin-Naumovic, D. Long, Optional protocol to the United Nations Convention against Torture and other Cruel, Inhuman or Degrading Treatment or Punishment. A manual for prevention, Genewa-San José 2005.

Burgers J.H., Danelius H., The United Nations Convention against torture. A handbook on the convention against torture and other cruel, inhuman, or degrading treatment or punishment, Dordrecht-Boston-London 1988.

Dawidziuk E., Dwa lata działalności Krajowego Mechanizmu Prewencji w Polsce wyniki wizytacji jednostek oraz placówek dla nieletnich, „Przegląd Więziennictwa Polskiego" 2010, nr 69.

Dawidziuk E., Traktowanie osób pozbawionych wolności we wspótczesnej Polsce na tle standardów międzynarodowych, Warszawa 2013.

Evans M.D., Haenni-Dale C., Preventing torture? The development of the Optional Protocol to the UN Convention against Torture, „Human Rights Law Review” 4, 2004, z. 1.

Fajst M., Ochrona praw osób uwięzionych w Polsce — systemy CPT i OPCAT, [w:] Przestrzeganie praw osób pozbawionych wolności. O monitoringu jednostek penitencjarnych, red. W. Klaus, M. Niełaczna, Warszawa 2008.

Frankfort-Nachmias Ch., Nachmias D., Metody badawcze w naukach spotecznych, przeł. E. Hornowska, Poznań 2001.

Lasocik Z., Zakaz tortur - systemowe gwarancje wolności od tortur w instytucjach izolujacych, [w:] Modernizowanie więziennictwa V Kongres Penitencjarny, red. T. Bulenda, A. Rzepliński, Warszawa 2015.

Nowa Kodyfikacja Prawa Karnego 54, 2019

(C) for this edition by CNS 
Mayntz R., Holm K., Hübner P., Wprowadzenie do metod socjologii empirycznej, przeł. W. Lipnik, Warszawa 1985.

Murray R., Steinerte E., Evans M., Hallo de Wolf A., The Optional Protocol to the UN Convention Against Torture, Oxford 2011.

Oppenheim A.N., Kwestionariusze, wywiady, pomiary postaw, przeł. S. Amsterdamski, Poznań 2004.

Raport Rzecznika Praw Obywatelskich z działalności w Polsce Krajowego Mechanizmu Prewencji w roku 2010, Biuletyn RPO 2011, nr 3. „Źródła”, red. S. Trociuk, Warszawa 2011.

Raport Rzecznika Praw Obywatelskich z działalności w Polsce Krajowego Mechanizmu Prewencji $w$ roku 2016, Biuletyn RPO 2017, nr 4. „Źródła”, red. A. Iwanowska, P. Kazimirski, J. Lewandowska, K. Olkowicz, Warszawa 2017.

Raport Rzecznika Praw Obywatelskich z działalności w Polsce Krajowego Mechanizmu Prewencji w roku 2017, Biuletyn RPO 2018, nr 4. „Źródła”, red. H. Machińska, A. Jędrzejczyk, P. Kazimirski, Warszawa 2018.

Steinerte E., The Jewel in the crown and its three guardians. Independence of National

Preventive Mechanisms under the Optional Protocol to the UN Torture Convention, „Human Rights Law Review” 14, 2014, z. 1.

Sułek A., Sondaż Polski. Przygarść rozpraw o badaniach ankietowych, Warszawa 2007. Sztumski J., Wstęp do metod i technik badań społecznych, Katowice 2005.

Theiss M., Metody zbierania danych - wywiady socjologiczne, [w:] B. Szatur-Jaworska, Ewaluacja w stuzbach społecznych, Warszawa 2010.

\section{The National Mechanism for the Prevention of Torture in the eyes of officers of the Prison Service}

Summary

The purpose of this study is to present the results of research conducted among officers and employees of the Prison Service regarding the knowledge and opinions of representatives of this professional group on the National Mechanism for the Prevention of Torture (hereinafter also KMPT, Mechanism).

Keywords: torture, punishment, principles of humanitarianism, human rights. 